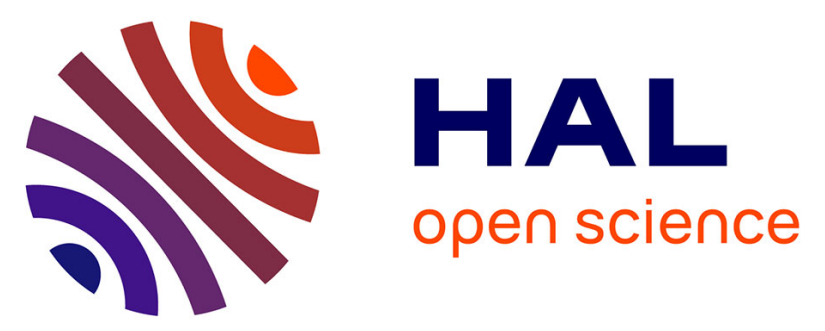

\title{
New Bioarchaeological Evidence and Radiocarbon Dates from the Lambayeque/Sicán Culture Camelids from the El Brujo Complex (Northern Coast of Peru): Implications for Funerary and Herd Management Practices
}

Francisca Santana-Sagredo, Elise Dufour, Nicolas Goepfert, Antoine Zazzo, Régulo Franco Jordán, Segundo Vásquez Sánchez

\section{- To cite this version:}

Francisca Santana-Sagredo, Elise Dufour, Nicolas Goepfert, Antoine Zazzo, Régulo Franco Jordán, et al.. New Bioarchaeological Evidence and Radiocarbon Dates from the Lambayeque/Sicán Culture Camelids from the El Brujo Complex (Northern Coast of Peru): Implications for Funerary and Herd Management Practices. Environmental Archaeology, inPress, 10.1080/14614103.2018.1556960 . hal01968637

\section{HAL Id: hal-01968637 \\ https://hal.science/hal-01968637}

Submitted on 2 Jan 2021

HAL is a multi-disciplinary open access archive for the deposit and dissemination of scientific research documents, whether they are published or not. The documents may come from teaching and research institutions in France or abroad, or from public or private research centers.
L'archive ouverte pluridisciplinaire HAL, est destinée au dépôt et à la diffusion de documents scientifiques de niveau recherche, publiés ou non, émanant des établissements d'enseignement et de recherche français ou étrangers, des laboratoires publics ou privés. 


\section{Environmental Archaeology}

The Journal of Human Palaeoecology

\section{New Bioarchaeological Evidence and Radiocarbon Dates from the Lambayeque/Sicán Culture Camelids from the El Brujo Complex (Northern Coast of Peru): Implications for Funerary and Herd Management Practices}

Francisca Santana-Sagredo, Elise Dufour, Nicolas Goepfert, Antoine Zazzo, Régulo Franco Jordán \& Segundo Vásquez Sánchez

To cite this article: Francisca Santana-Sagredo, Elise Dufour, Nicolas Goepfert, Antoine Zazzo, Régulo Franco Jordán \& Segundo Vásquez Sánchez (2018): New Bioarchaeological Evidence and Radiocarbon Dates from the Lambayeque/Sicán Culture Camelids from the El Brujo Complex (Northern Coast of Peru): Implications for Funerary and Herd Management Practices, Environmental Archaeology

To link to this article: https://doi.org/10.1080/14614103.2018.1556960

曲 Published online: 20 Dec 2018.

Submit your article to this journal \lceil

View Crossmark data 


\title{
New Bioarchaeological Evidence and Radiocarbon Dates from the Lambayeque/Sicán Culture Camelids from the El Brujo Complex (Northern Coast of Peru): Implications for Funerary and Herd Management Practices
}

\author{
Francisca Santana-Sagredo ${ }^{\mathrm{a}, \mathrm{b} *}$, Elise Dufour ${ }^{\circledR a}{ }^{\mathrm{a}}$, Nicolas Goepfert $\mathbb{C}^{\mathrm{b}}$, Antoine Zazzo ${ }^{\mathrm{a}}$, Régulo Franco Jordán ${ }^{\mathrm{c}}$ \\ and Segundo Vásquez Sánchez ${ }^{\mathrm{d}}$ \\ ${ }^{a}$ Archéozoologie, Archéobotanique: Sociétés, pratiques et environnements (AASPE), UMR 7209, Muséum national d'Histoire naturelle, \\ CNRS, Paris, France; ${ }^{b}$ CNRS-Paris 1, UMR 8096 Archéologie des Amériques, Nanterre, France; ${ }^{C}$ Museo de Cao-Fundación Wiese, Lima, Peru; \\ dUniversidad Nacional de Trujillo (UNT), Ciudad Universitaria, Trujillo, Perú
}

\begin{abstract}
Pastoralism and camelid management have been essential to all aspects of pre-Hispanic Andean societies. Here, we present zooarchaeological and isotopic data on domestic camelid remains from Huaca Cao Viejo (El Brujo archaeological complex) on the northern coast of Peru, and dated to the Lambayeque/Sicán period-to characterise their biological age, diet, life history, possible geographic origin and ritual use. Domestic camelids, representing a wide range of biological ages and a high rate of polydactyly, were found as burial offerings in direct association with human funerary bundles (fardos). Direct AMS dates indicated that camelids were buried over a short period of time (AD 1022-1176) confirming the Lambayeque presence in the Chicama Valley during the first half of the Late Intermediate Period. Stable isotopic analyses were carried out on both bone collagen and hair keratin, including incremental analysis. A considerable variability in $\delta^{13} \mathrm{C}$ values at both the intraindividual and the intra-group level and a large contribution of $C_{4}$ resources to diet are shown. This clearly supports local management and camelids originating from various herds. Zooarchaeological and isotopic evidences suggest diversity in herding practices and suggest the importance of the herds in fulfilling the transportation demands for trade in goods.
\end{abstract}

ARTICLE HISTORY

Received 26 June 2018

Revised 14 November 2018

Accepted 28 November 2018

\section{KEYWORDS}

Coastal herding; domestic camelids; Northern Peru; stable isotope analysis; bone collagen; hair keratin; radiocarbon dating; individual age

\section{Introduction}

Pastoralism and domestic camelid management have been essential to the economic, political, social, cultural and ritual aspects of pre-Hispanic Andean societies (Bonavia 1996; Capriles and Tripcevich 2016; Flores Ochoa, MacQuarrie, and Portus 1994, among others). Domesticated camelids (llama [Lama glama] and alpaca [Vicugna pacos]) played a significant role in the structure of these complex societies, as beasts of burden, as a source of food and secondary products (wool, bone, leather, etc.), and in ritual practices. Even though available ethnographic and ethnohistorical evidence suggests that over the past 40 decades camelid pastoralism was a high-altitude activity (Murra 1972, 1985), these prevailing paradigms have recently started to be challenged by archaeological and isotopic studies. Local herding in the coast and low and middle valleys of northern Peru was first proposed by Shimada and Shimada (1985) and is now supported by different studies (Dufour et al. 2014; Floreano Salinas 2016; Goepfert 2012; Goepfert et al. 2013; Lozada et al. 2009; Szpak et al. 2014, 2015; Szpak, Chicoine et al. 2016; Szpak, Millaire et al.
2016; Thornton et al. 2011). Most of these studies have focused on the Early Intermediate Period (EIP; 200 BC-AD 800) and Middle Horizon (MH; AD 600-1000) of northern Peru. There is a relative lack of research using stable isotope analysis (SIA) for the Late Intermediate Period (LIP; AD 1000-1470) in general and in the Lambayeque/Sicán culture (hereafter called the Lambayeque culture) in particular, with two studies on camelid remains and textiles from Pacatnamú, in the Jequetepeque valley (Szpak et al. 2018; Verano and DeNiro 1993), and two studies on human remains, from Pacatnamú (White et al. 2009) and from Huaca Loro (Knudson 2014), published so far. The majority of the archaeological investigations into this culture concentrate on the Lambayeque valley (Fernández Alvarado and Wester La Torre 2014; Shimada 1981, 1995, 2014a; Wester La Torre 2016, among others), and there are few studies outside this valley (Franco Jordán, Gálvez Mora, and Vásquez Sánchez 2007; Franco Jordán and Gálvez Mora 2005, 2014; Prieto Burmester 2014).

The Lambayeque culture developed on the northern coast of what is now Peru from AD 800/850 to 1350 
and extended from the Piura valley, in the north, to the Chicama valley, in the south (Figure 1). The most important Lambayeque sites are Tucume and Chotuna-Chornancap, in the lower Lambayeque valley, and Huaca Loro and Huacas Las Ventanas, in the Bosque de Pomac sanctuary. The Lambayeque culture was thought to represent a centralised state with a capital city, a role played by the sites of the Bosque de Pomac until AD 1100 (Shimada 1981, 2014a) and by the site of Tucume from AD 1100 until the Chimú conquest in AD 1300 (Moore and Mackey 2008). This model of a centralised state with a capital is now being challenged by new archaeological evidence of other centres of power, such as the 'priestesses' tombs at Chornancap (Wester La Torre 2016). As was the case during the preceding Mochica period, during the Lambayeque period, the use of domestic camelids was considerable, including in textile production and funerary rituals (Shimada 2014a; Shimada and Shimada 1985). In fact, there is evidence that the importance of camelids in coastal societies increased at this time, as testified to by their unprecedented representation in the murals of Huaca Las Balsas, at Tucúme (Narváez and Delgado 2011).

After the collapse of the Mochica culture, Huaca Cao Viejo, located at El Brujo complex, in the Chicama

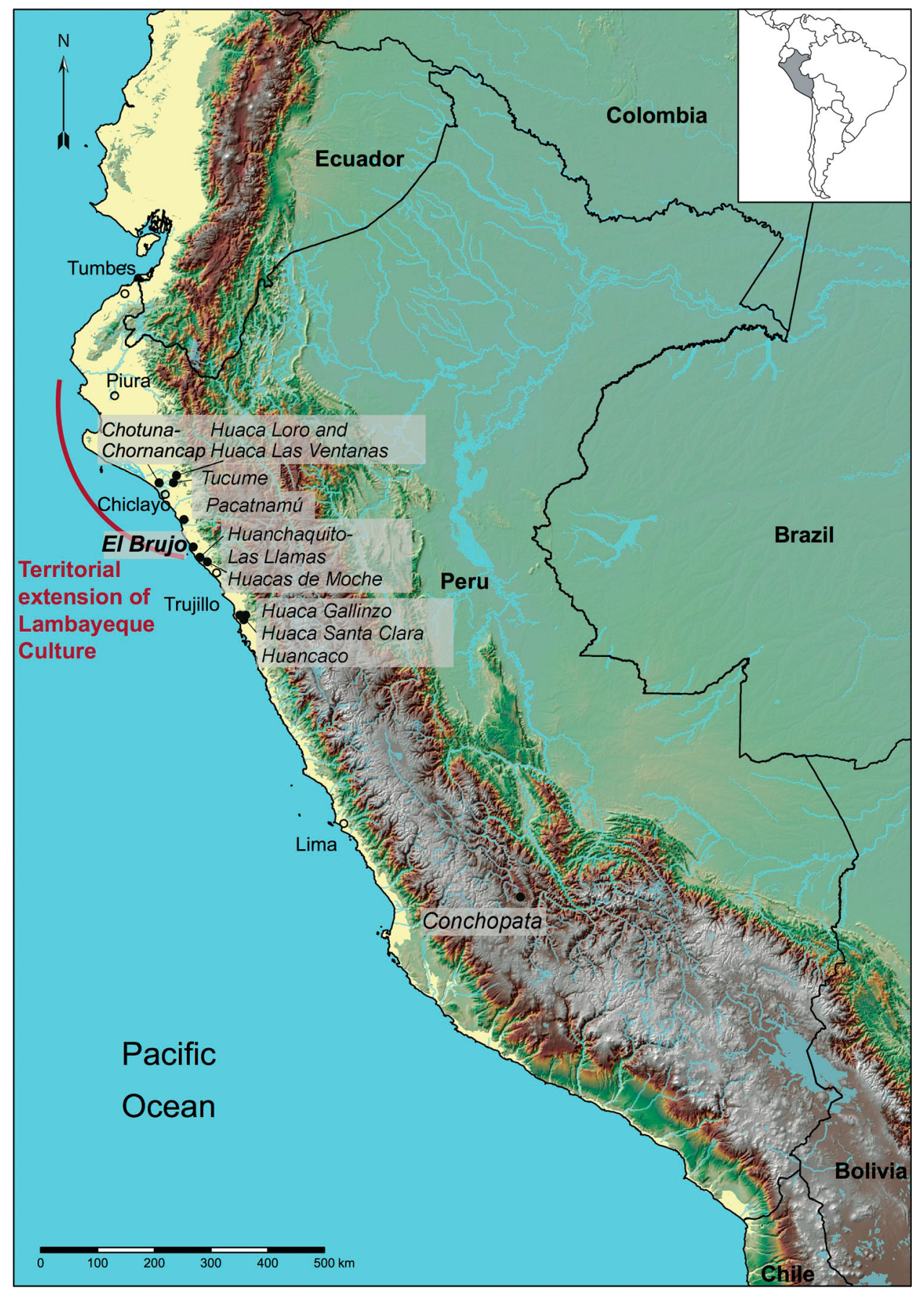

Figure 1. Map showing the location of El Brujo, archaeological sites and the maximum territorial extent associated with the Lambayeque culture on the northern Peruvian coast, together with archaeological sites and modern cities cited in the text. 
valley, was reused by the Lambayeque as a place of burial for tens of funerary bundles, also called fardos (Franco Jordán, Gálvez Mora, and Vásquez Sánchez 2007; Franco Jordán and Gálvez Mora 2005, 2014; Mujica Barreda et al. 2007). These bundles are composed of humans wrapped in textile and are associated with goods and other offerings, in particular camelids. Owing to the excellent state of preservation of the remains and the timing of their deposition, the camelid finds relating to the Lambayeque occupation at the El Brujo complex provide an exceptional testimony of the use of camelids in funerary contexts (Figure 2). Previous studies on camelids from Huaca Cao Viejo (Kent, Vásquez Sánchez, and Rosales Tham 2001) and sites dated from the Mochica period (Goepfert 2011, 2012) showed that the camelids funerary deposits are mainly represented by heads and fore and hind limbs. Some of the animal remains were studied by Kent, Vásquez Sánchez, and Rosales Tham (2001) to test methods of taxonomic determination. In fact, discriminating among the two domestic and two wild species (Lama guanicoe and Vicugna vicugna) based on osteological remains is difficult. Kent, Vásquez Sánchez, and Rosales Tham (2001) also considered the presence of congenital malformation, such as polydactyly, as an indicator of herding intensification. However, these previous studies provide no information on individual

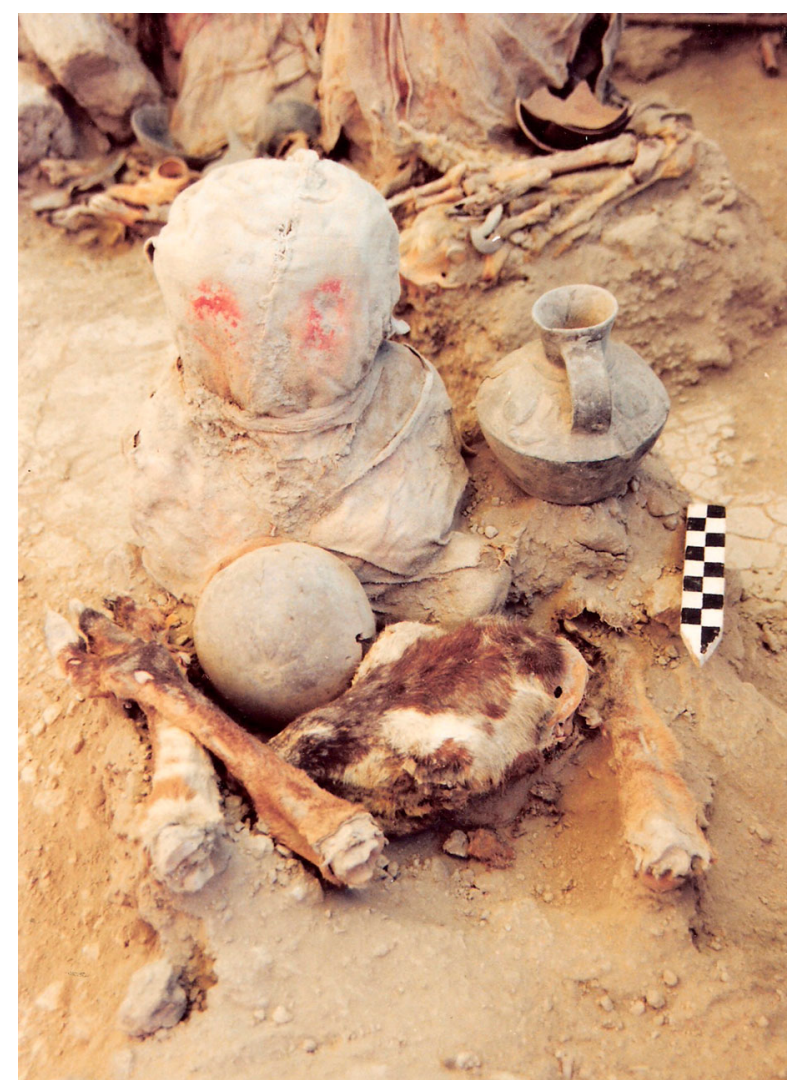

Figure 2. Lambayeque funerary bundle (or fardo) deposited at El Brujo. The head and fore and hind limbs of a camelid with a mixed colour coat (beige and brown) were deposited to the north of the human. age and geographic origin of the camelids used in ritual activities. Here, we present new zooarchaeological, isotopic and radiocarbon data relating to a sample of the Huaca Cao Viejo camelids, with the following four objectives:

The first objective is to obtain insight into the funerary practices linked to animals at Huaca Cao Viejo based on the estimation of camelid individual age and the determination of camelid life history through SIA of bone collagen and hair, which will allow us to compare different moments in the life of the individuals. The second objective is to reconstruct the diet and geographic origin of the camelids, with the aim of contributing to the description of herding practices for the northern coast of Peru. While the material culture of the funerary contexts has been described previously (Franco Jordán, Gálvez Mora, and Vásquez Sánchez 2007; Franco Jordán and Gálvez Mora 2005, 2014; Mujica Barreda et al. 2007), thus far direct dates have been lacking. Therefore, the third objective of this work is to provide a new ${ }^{14} \mathrm{C}$ dating framework that will allow us to understand the chronology of the deposits. The fourth objective is to compare our data with those from other sites and, from there, to discuss ritual and herd management practices during the LIP.

\section{Previous Stable Isotope Research on Plants and Domestic Camelids in Peru}

Recent isotopic studies have focused on the management of camelid herds on the coast and in the highland of Peru (Dufour et al. 2014; Szpak et al. 2013, 2014; Thornton et al. 2011), as well as on the origin of wool used in textiles (Szpak et al. 2015). These studies based their interpretations about coastal herding on camelid diet as determined based on systematic environmental isotopic variations.

Szpak et al. (2013) carried out a plant survey in northern Peru, sampling plants from the coast to the highlands in order to document $\mathrm{C}_{3}$ and $\mathrm{C}_{4}$ plant cover and distribution in the lowlands and the puna (above 3.800 masl). $\mathrm{C}_{3}$ and $\mathrm{C}_{4}$ plants each follow a particular photosynthetic pathway, which leads to differences in their carbon isotopic compositions. The $\mathrm{C}_{3}$ photosynthetic pathway discriminates against ${ }^{13} \mathrm{C}$, leading to lower values of $\delta^{13} \mathrm{C}$, whereas the $\mathrm{C}_{4}$ pathway allows ${ }^{13} \mathrm{C}$ to be incorporated into the plant's tissues through photosynthesis (Farquhar, Ehleringer, and Hubick 1989). The cover and distribution of $\mathrm{C}_{3}$ and $\mathrm{C}_{4}$ plants depend on altitude and the amount of rainfall; at higher altitudes (above 3500 masl), the amount of rainfall increases (to close to $400 \mathrm{~mm}$ ) and the vegetation cover consists almost exclusively of $\mathrm{C}_{3}$ plants (Szpak et al. 2013; Tieszen and Chapman 1992). Puna ecology is characterised by the presence of bofedales, which, comprising water resources as well as vegetation, are ideal places for camelid pasture 
(Fernández and Panarello 1999-2001; MaldonadoFonkén 2014-2015). $C_{3}$ plants also dominate other ecological zones in northern Peru and in the central and south-central Andes (Szpak et al. 2013; Tieszen and Chapman 1992). In contrast, at lower altitudes, $\mathrm{C}_{4}$ plants are more frequent, as supported by Szpak et al.'s survey (2013).

Hyperarid conditions in the northern coast of Peru, which dominate the region (Rundel et al. 1991), result in higher $\delta^{15} \mathrm{~N}$ values in plants (Heaton 1987). Therefore plants growing at the coast, where precipitation is almost absent, should have higher $\delta^{15} \mathrm{~N}$ values. Following this logic, modern and archaeological camelids grazing in the highlands (above 3800 masl) should present lower values of $\delta^{13} \mathrm{C}$ and $\delta^{15} \mathrm{~N}$ than those grazing on the coast (DeNiro 1988; Dufour et al. 2014; Fernández and Panarello 1999-2001; Szpak et al. 2014, 2015; Yacobaccio, Morales, and Samec 2009). However, these differences are not always present. Even though $\mathrm{C}_{4}$ plants are more prevalent at lower elevations, their distribution covers an area from 0 up to 3000 masl in northern Peru (Szpak et al. 2013), rendering it difficult to distinguish between coastal, middle valley and pre-cordilleran (below 2.000 masl) camelid grazing areas. In addition, because $\mathrm{C}_{3}$ plants are dominant in all the ecological zones, camelids with low $\delta^{13} \mathrm{C}$ could, in theory, have consumed $\mathrm{C}_{3}$ vegetation anywhere from the lowlands to the puna. Carbon isotope values can also be affected by aridity, which would result in enrichment in the plants' composition (Ehleringer et al. 1998) and, in turn, an increase in the $\delta^{13} \mathrm{C}$ values of the camelids. Finally, it is worth noting that, even though there is an isotopic baseline for northern Peru (Szpak et al. 2013), plant values can show variability within similar environments.

In the lowlands of northern Peru, particularly on the hyperarid coast, places suited to camelid pasturing are limited, being restricted to areas adjacent to the beach, to river courses, and to lomas ('oases of fog') in the Andean foothills. The lomas vegetation, which grows seasonally thanks to the humidity provided by the ocean fog, is composed of diverse species of grass, shrubs and trees. The most common $\mathrm{C}_{4}$ species on the coast is Distichlis spicata (Grama salada) (Szpak et al. 2013), which can form large patches locally. The valleys bring water from the mountains that allows for the development of the largest natural grazing areas (not only on the coast, but also in the sierra). Wild $\mathrm{C}_{3}$ plants and fruits are also present in this area including algarrobo (Prosopis sp.) and acacia (Vachellia sp., previously Acacia sp.) (Ebinger, Seigler, and Clarke 2000; Mostacero and Mejía 1993; Ugent and Ochoa 2006). Agricultural activities in the valleys involved the management of irrigated fields for different types of crops, including maize $\left(\mathrm{C}_{4}\right)$ (Zea mays), beans $\left(\mathrm{C}_{3}\right)$ (Phaseolus vulgaris), peanuts $\left(\mathrm{C}_{3}\right)$ (Arachis hypogaea) and avocados $\left(\mathrm{C}_{3}\right)$ (Persea americana). Camelids may have had access to these field crops, leading to foddering, in particular of maize, as has been previously suggested by Finucane, Maita Agurto, and Isbell (2006) for the sierra of southern Peru and by Dufour et al. $(2014,2018)$ for the northern coast of Peru.

\section{Materials and Methods}

\section{Site Presentation}

El Brujo is an archaeological complex situated in the Chicama valley, $45 \mathrm{~km}$ north of the modern-day city of Trujillo, the capital of the region of La Libertad (Figure 1). The El Brujo complex is located on a geological terrace and comprises two Mochica pyramids (huacas), Huaca Cao Viejo and Huaca El Brujo, or Cortada (Franco Jordán, Gálvez Mora, and Vásquez Sánchez 2005). An artificial mound, Huaca Prieta, dating from the Preceramic (Bird, Hyslop, and Skinner 1985; Dillehay 2017), and a set of platform and domestic sectors surround these structures. The Lambayeque occupations are evidenced by the presence of burials and material culture in the northern portion of Huaca Cao Viejo (Franco Jordán, Gálvez Mora, and Vásquez Sánchez 2007; Mujica Barreda et al. 2007). While funerary chambers were used during the Moche period, circular pits were used during the Lambayeque period. The funerary bundles found in these pits had been buried together with a considerable amount of burial goods, including copper objects, such as masks, headdresses and sceptres; textiles of different colours and shapes; pottery vessels, including vessels of 'Huaco Rey' type which is characteristic of Lambayeque funerary contexts; and miscellaneous objects, such as cotton, shellfish (including Spondylus sp.), beads, and flutes made of animal bones (Franco Jordán, Gálvez Mora, and Vásquez Sánchez 2007; Franco Jordán and Gálvez Mora 2014). The burials also included camelids (Figure 2). The camelids in these burials were usually not anatomically complete, consisting of only heads and feet with preserved skin and hair. It is worth noting that some burials contained more goods than others, suggesting possible elite burials or status differences within the funerary area (Franco Jordán and Gálvez Mora 2014).

\section{Camelid Selection and Zooarchaeological Analysis}

For the current study, a total of 32 domestic camelid individuals coming from 31 funerary contexts (out of the 393 recorded at Huaca Cao Viejo; Mujica Barreda et al. 2007, 262) were selected (Table 1) and exported under permission obtained from the Ministerio de Cultura of Peru ( $\left.{ }^{\circ} 142-2015-V M P C I C / M C\right)$. Bone collagen was taken from all 32 individuals and hair was taken from 13 of them for stable isotope analysis 
(Table 2). In all but one case, hair was sampled directly from the bone. The exception concerns individual \# 13; a large amount of loose hair was found associated with its bones, but not directly attached to them. Because we could not discard the possibility that the hair does not belong to the same individual as the bones, the hair sample was called \# 13b, to clearly distinguish it from the bone sample.

Taxonomic determination based on osteological analysis is difficult for the South American camelids due to the close anatomical resemblance among the four species. A previous study on 21 camelids from Huaca Cao Viejo used enamel repartition on the incisor crown and phalange osteometry as criteria for taxonomic differentiation, but this led to conflicting taxonomic determinations (Kent, Vásquez Sánchez, and Rosales Tham 2001). In that same study, pathologies were considered as suggestive of the presence of the two domesticated species, llamas and alpacas. Unfortunately, because there is no indication in Kent, Vásquez Sánchez, and Rosales Tham (2001) about the context the individuals derived from, we cannot know whether they belong to the same individuals that we analysed in the present study. Taxonomic identification was based on the Kent, Vásquez Sánchez, and Rosales Tham (2001) study and our own observation of pathologies and colour patterns. We assume that all the individuals in the present study are domestic, rather than wild, camelids (Table 1). Age at death was estimated based on dental eruption and tooth wear (Wheeler 1982; Table 1).

\section{Bone and Hair Preparation and Stable Isotope Analysis}

Bone and hair samples were selected in order to compare different moments in the life of the individuals. Bone collagen should represent the diet consumed during the last years of life of the individual (Hedges et al. 2007), while hair should reflect the diet consumed during the last months before death, assuming hair grows at a rate of about $1-2 \mathrm{~cm}$ per month (Jones et al. 1981; O'Connell et al. 2001; Zazzo et al. 2007).

The skeletal elements selected for collagen extraction comprised phalanges and, in one case only, a talus (Table 1). The bone was mechanically cleaned by abrasion using a tungsten drill tool. The sample was then cut into subsamples of $1 \mathrm{gr}$, which were ground to powder. After being sieved to select grain sizes of between 300 and $750 \mu \mathrm{m}, 200 \mathrm{mg}$ of each sample was used for collagen extraction, using an adaptation of the Longin (1971) method, as described in Dufour et al. (2018). The bone was demineralised in a $1 \mathrm{M} \mathrm{HCl}$ solution for $20 \mathrm{~min}$ at room temperature. Due to the excellent preservation of organic material in northern Peru, one or two 45 min treatments in $\mathrm{NaOH}$ were sufficient to remove any humic acids present. The samples were then solubilised in $\mathrm{pH}=2$ water and later freeze-dried. Hair samples were cleaned and sonicated several times in a methanol:chloroform (2:1) solution then dried at room temperature. Hair strands from the 6 camelids with hair samples longer than $1 \mathrm{~cm}$ were cut every $1 \mathrm{~cm}$ from root to tip, after which each increment was analysed separately.

For $\delta^{13} \mathrm{C}$ and $\delta^{15} \mathrm{~N}$ measurement, between 300 and $500 \mu \mathrm{g}$ of bone collagen and 320 and $380 \mu \mathrm{g}$ of hair keratin from each sample were combusted in a Elemental Analyser Flash 2000 coupled with a Delta V Advantage (Thermo Scientific) isotope ratio mass spectrometer, at the Service de Spectrométrie de Masse Isotopique du Muséum at the Muséum national d'Histoire naturelle in Paris. Mass spectrometer analytical error was 0.34 $\%$ for $\delta^{13} \mathrm{C}$ and $0.02 \%$ o for $\delta^{15} \mathrm{~N}$, based on replicate analysis of an internal standard (alanine) calibrated against the international standard IAEA 600.

The results for bone collagen and hair keratin are presented as $\delta^{13} \mathrm{C}_{\text {coll }}$ and $\delta^{15} \mathrm{~N}_{\text {coll }}$, and $\delta^{13} \mathrm{C}_{\mathrm{ker}}$ and $\delta^{15} \mathrm{~N}_{\text {ker }}$, respectively.

\section{Radiocarbon Dating}

Radiocarbon dating was carried out on 5 bone collagen samples, following the same extraction protocols used for the stable isotope analysis. About $2.5 \mathrm{mg}$ of collagen was wrapped in an ultra-light tin capsule, combusted in the elemental analyser (EA), and then transferred to the graphitisation unit of an AGE 3 automated compact graphitisation system. Reduction was performed in seven quartz reactors, each containing $5 \mathrm{mg}$ of iron catalyst. Prior to the processing of each sample that was to be dated, an aliquot of this sample was combusted in order to minimise memory effects. The graphite samples were then pressed into targets. Two oxalic acid II standards and two phtalic anhydride blanks were processed together with the unknowns every 10 samples. Graphite targets were dated using the compact AMS ECHoMICADAS at Gif-sur-Yvette (France). Data reduction was performed using BATS software (version 4.07). Radiocarbon dates were calibrated using the SHCal13 curve (Hogg et al. 2013) in the OxCal Program v 4.2.4 (Bronck Ramsey and Lee 2013).

\section{Statistical Analysis}

In order to estimate proportion of $\mathrm{C}_{3}$ to $\mathrm{C}_{4}$ in the Huaca Cao Viejo camelids' diet, the $\delta^{13} \mathrm{C}$ values of collagen were analysed using Bayesian mixing modelling in SIAR (Parnell et al. 2010). A diet-collagen fractionation of $+3.7 \pm 1.6 \%$ and a diet-hair keratin fractionation of $+2.4 \pm 1.2 \%$ were used for estimating $\mathrm{C}_{3} / \mathrm{C}_{4}$ contributions (Szpak et al. 2014, 2018). Mean values for $\delta^{13} \mathrm{C}$ in $\mathrm{C}_{3}(-26.01 \pm 1.75)$ and $\mathrm{C}_{4}$ $(-12.01 \pm 0.95 \%)$ plants were obtained from the 


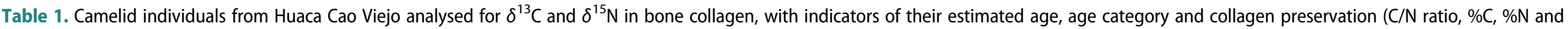
collagen yield).

\begin{tabular}{|c|c|c|c|c|c|c|c|c|c|c|c|c|c|}
\hline Individual (\#) & Sample number & Burial & Age & Age Category & Coat colour & Polydactyly & Bone & $\delta^{13} C_{\text {coll }}$ & $\delta^{15} \mathrm{~N}_{\text {coll }}$ & $\% C$ & $\% \mathrm{~N}$ & $\mathrm{C} / \mathrm{N}$ & \%Collagen \\
\hline 1 & LCV 14 & E31 (92) & Unknown & Unknown & Brown & & Phalange & -12.9 & 7.7 & 38.57 & 14.21 & 3.1 & 25.9 \\
\hline 2 & LCV 17 & E29 (92) & Unknown & Unknown & Brown & & Phalange & -12.9 & 7.4 & 41.47 & 15.34 & 3.1 & 21.2 \\
\hline 3 & LCV 18 & E72 (92) & Unknown & Unknown & Unknown & & Phalange & -12.4 & 8.4 & 40.60 & 15.06 & 3.1 & 19.1 \\
\hline 4 & LCV 20 & E14 (92) & Unknown & Unknown & Brown & & Phalange & -14.8 & 5.7 & 41.65 & 15.34 & 3.1 & 14.7 \\
\hline 5 & LCV 22 & E41 (92) & Unknown & Unknown & Unknown & & Phalange & -12.2 & 7.9 & 40.04 & 14.71 & 3.1 & 21.4 \\
\hline 6 & LCV 23 & E7Dist (92) & Unknown & Unknown & Mixed beige and brown & & Phalange & -13.5 & 6.5 & 39.00 & 14.32 & 3.1 & 14.4 \\
\hline 7 & LCV 25 & E16 (92) & Unknown & Unknown & Beige & & Phalange & -10.4 & 8.0 & 41.49 & 15.36 & 3.1 & 19.4 \\
\hline 8 & LCV 29 & E12 (92) & 6 months & Juvenile (1) & Beige & & Phalange & -8.7 & 6.4 & 40.76 & 14.59 & 3.2 & 24.2 \\
\hline 9 & LCV 34 & E43 (92) & $6-9$ months & Juvenile (1) & Unknown & & Phalange & -11.2 & 7.1 & 40.01 & 14.63 & 3.1 & 13.3 \\
\hline 10 & LCV 36 & E108 (92) & Unknown & Unknown & Beige & & Phalange & -13.0 & 8.2 & 40.91 & 15.01 & 3.1 & 18.1 \\
\hline 11 & LCV 38 & E10 (95) & $3-6$ months & Juvenile (1) & Mixed beige and brown & Yes & Phalange & -13.9 & 7.6 & 39.29 & 14.41 & 3.1 & 20.0 \\
\hline 12 & LCV 41 & E32 (92) & $3-6$ months & Juvenile (1) & Unknown & & Phalange & -11.3 & 7.3 & 40.46 & 14.64 & 3.2 & 22.3 \\
\hline 13 & LCV 44 & E77 (91) & 9 months -1 year & Juvenile (1) & Unknown & & Phalange & -15.4 & 5.4 & 39.38 & 14.34 & 3.2 & 17.4 \\
\hline 14 & LCV 46 & E56 (91) & Unknown & Unknown & Mixed beige and brown & & Phalange & -11.2 & 7.4 & 40.09 & 14.40 & 3.2 & 13.1 \\
\hline 15 & LCV 51 & E84 (91) & $1-3$ months & Juvenile (1) & Mixed beige and brown & & Phalange & -11.2 & 7.4 & 41.41 & 15.27 & 3.1 & 15.2 \\
\hline 16 & LCV 56 & E84 (91) & 14 years + & Adult (4) & Mixed beige and brown & & Phalange & -10.7 & 8.3 & 40.71 & 14.98 & 3.1 & 13.7 \\
\hline 17 & LCV 61 & E32 (92) & 2 years and $6-9$ months & Sub-Adult (2) & Brown & & Phalange & -14.5 & 5.9 & 41.71 & 15.21 & 3.2 & 14.2 \\
\hline 18 & LCV 65 & E11 (95) & 2 years and 6 months -3 years & Sub-Adult (2) & Beige & Yes & Phalange & -12.6 & 7.8 & 41.88 & 15.45 & 3.1 & 15.0 \\
\hline 19 & LCV 70 & $\mathrm{~T} 1$ (95) & 4 years and 9 months & Adult (3) & Brown & & Phalange & -13.2 & 7.4 & 41.19 & 14.74 & 3.2 & 17.1 \\
\hline 20 & LCV 76 & E1B (95) & $5-7$ years & Adult (3) & Brown & & Phalange & -14.9 & 5.2 & 41.99 & 15.29 & 3.2 & 13.3 \\
\hline 21 & LCV 82 & E89 (91) & 5 years and 9 months -7 years and 6 months & Adult (3) & Brown & & Phalange & -12.0 & 7.9 & 40.73 & 14.71 & 3.2 & 12.7 \\
\hline 22 & LCV 88 & E42 (92) & $8-10$ years & Adult (4) & Unknown & & Phalange & -14.0 & 7.8 & 42.49 & 15.84 & 3.1 & 12.9 \\
\hline 24 & LCV 93 & E92 (91) & 9 years and 6 months -10 years and 6 months & Adult (4) & Unknown & & Phalange & -9.6 & 8.2 & 40.74 & 14.62 & 3.2 & 14.9 \\
\hline 25 & LCV 99 & E18 (95) & $9-11$ years & Adult (4) & Mixed beige and brown & Yes & Phalange & -13.1 & 7.0 & 41.63 & 15.37 & 3.1 & 14.4 \\
\hline 26 & LCV 105 & E1 (92) & 9 years and 6 months -13 years and 6 months & Adult (4) & Unknown & & Phalange & -12.4 & 7.9 & 39.17 & 14.38 & 3.1 & 9.2 \\
\hline 27 & LCV 107 & E17 (95) & 14 years + & Adult (4) & Mixed beige and brown & & Phalange & -16.5 & 4.7 & 40.74 & 15.07 & 3.1 & 9.8 \\
\hline 28 & LCV 111 & E55 (91) & Unknown & Unknown & Mixed beige and brown & & Phalange & -14.4 & 5.8 & 41.23 & 14.92 & 3.2 & 17.7 \\
\hline 29 & LCV 113 & E55 (91) & Unknown & Unknown & Beige & Yes & Phalange & -12.0 & 6.2 & 40.80 & 14.92 & 3.1 & 14.8 \\
\hline 30 & LCV 116 & E80 (91) & Unknown & Unknown & Mixed beige and brown & & Phalange & -12.5 & 6.4 & 40.67 & 14.94 & 3.1 & 20.3 \\
\hline 31 & LCV 119 & E9 (92) & 14 years + & Adult (4) & Brown & & Phalange & -11.4 & 9.5 & 41.66 & 14.83 & 3.2 & 16.1 \\
\hline 32 & LCV 122 & E46 (92) & 1 and 3 months -1 and 6 months & Juvenile (1) & Unknown & & Talus & -13.3 & 7.2 & 39.66 & 14.60 & 3.1 & 14.1 \\
\hline 33 & LCV 125 & E64 (91) & 2 years and 6 months -2 years and 9 months & Sub-Adult (2) & Mixed beige and brown & & Phalange & -15.6 & 5.7 & 38.61 & 13.89 & 3.2 & 13.4 \\
\hline
\end{tabular}


Table 2. Camelid individuals from Huaca Cao Viejo analysed for $\delta^{13} \mathrm{C}$ and $\delta^{15} \mathrm{~N}$ in hair keratin, with indicators of their keratin preservation ( $\mathrm{C} / \mathrm{N}$ ratio, $\% \mathrm{C}$ and $\% \mathrm{~N})$.

\begin{tabular}{|c|c|c|c|c|c|c|c|c|c|c|c|c|}
\hline $\begin{array}{l}\text { Individual } \\
\text { (\#) }\end{array}$ & $\begin{array}{l}\text { Sample } \\
\text { number }\end{array}$ & Burial & Age & $\begin{array}{c}\text { Age } \\
\text { Category }\end{array}$ & Coat colour & Polydactyly & $\delta^{13} C_{\text {ker }}$ & $\delta^{15} \mathrm{~N}_{\mathrm{ker}}$ & $\begin{array}{l}\text { Distance } \\
\text { from } \\
\text { skin }(\mathrm{cm})\end{array}$ & $\% \mathrm{C}$ & $\% \mathrm{~N}$ & $\begin{array}{l}\mathrm{C} / \\
\mathrm{N}\end{array}$ \\
\hline 1 & LCV 15 & E31 (92) & unknown & Unknown & Brown & & -15.3 & 7.3 & 1.0 & 53.95 & 17.26 & 3.6 \\
\hline 3 & LCV 19 & E72 (92) & unknown & Unknown & Brown & & -16.4 & 9.0 & 1.0 & 43.65 & 14.44 & 3.5 \\
\hline 8 & LCV 30 & E12 (92) & 6 months & Unknown & Unknown & & -10.2 & 6.5 & 1.0 & 44.92 & 14.65 & 3.5 \\
\hline 11 & LCV 39-A & E10 (95) & $3-6$ months & $\begin{array}{l}\text { Juvenile } \\
\text { (1) }\end{array}$ & $\begin{array}{l}\text { Mixed beige } \\
\text { and brown }\end{array}$ & Yes & -15.7 & 8.6 & 1.0 & 48.26 & 15.92 & 3.5 \\
\hline 11 & LCV 39-B & & & & & & -16.0 & 7.2 & 2.0 & 46.11 & 15.40 & 3.4 \\
\hline 11 & LCV 39-C & & & & & & -15.3 & 7.9 & 3.0 & 43.79 & 14.42 & 3.5 \\
\hline 11 & LCV 39-D & & & & & & -14.7 & 8.7 & 4.0 & 43.93 & 14.60 & 3.5 \\
\hline 11 & LCV 39-E & & & & & & -14.1 & 8.8 & 5.0 & 42.68 & 14.13 & 3.5 \\
\hline $13 b$ & LCV 45-A & E77 (91) & Unknown & Unknown & & & -11.6 & 8.9 & 1.0 & 43.53 & 14.91 & 3.4 \\
\hline $13 b$ & LCV 45-B & & & & & & -9.4 & 9.2 & 2.0 & 43.17 & 14.70 & 3.4 \\
\hline $13 b$ & LCV 45-C & & & & & & -10.4 & 9.1 & 3.0 & 43.19 & 14.45 & 3.4 \\
\hline $13 b$ & LCV 45-D & & & & & & -12.6 & 8.2 & 4.0 & 42.92 & 14.78 & 3.3 \\
\hline $13 b$ & LCV 45-E & & & & & & -12.5 & 8.2 & 5.0 & 42.18 & 14.63 & 3.3 \\
\hline $13 b$ & LCV 45-F & & & & & & -11.2 & 8.6 & 6.0 & 42.67 & 14.73 & 3.3 \\
\hline $13 b$ & LCV 45-G & & & & & & -10.4 & 8.8 & 7.0 & 41.76 & 13.78 & 3.5 \\
\hline $13 b$ & LCV 45-H & & & & & & -10.1 & 8.9 & 8.0 & 42.20 & 14.20 & 3.4 \\
\hline $13 b$ & LCV 45-I & & & & & & -10.8 & 8.9 & 9.0 & 41.42 & 14.25 & 3.3 \\
\hline $13 b$ & LCV 45-J & & & & & & -12.9 & 8.3 & 10.0 & 42.55 & 14.43 & 3.4 \\
\hline $13 b$ & LCV 45-K & & & & & & -12.9 & 8.0 & 11.0 & 41.22 & 14.04 & 3.4 \\
\hline $13 b$ & LCV 45-L & & & & & & -12.3 & 8.9 & 12.0 & 41.80 & 14.03 & 3.4 \\
\hline $13 b$ & LCV 45-M & & & & & & -11.5 & 9.0 & 13.0 & 35.43 & 12.22 & 3.3 \\
\hline $13 b$ & LCV 45-N & & & & & & -10.7 & 9.3 & 14.0 & 41.93 & 14.15 & 3.4 \\
\hline 16 & LCV 58-A & E84 (91) & 14 years + & $\begin{array}{l}\text { Juvenile } \\
\text { (1) }\end{array}$ & $\begin{array}{l}\text { Mixed beige } \\
\text { and brown }\end{array}$ & & -11.9 & 9.3 & 1.0 & 41.32 & 13.56 & 3.5 \\
\hline 16 & LCV 58-B & & & & & & -11.4 & 9.3 & 2.0 & 42.91 & 14.16 & 3.5 \\
\hline 16 & LCV 58-C & & & & & & -10.7 & 9.5 & 3.0 & 41.06 & 13.07 & 3.6 \\
\hline 16 & LCV 58-D & & & & & & -11.2 & 8.9 & 4.0 & 42.58 & 13.98 & 3.5 \\
\hline 16 & LCV 58-E & & & & & & -11.4 & 8.7 & 5.0 & 43.75 & 14.49 & 3.5 \\
\hline 16 & LCV 58-F & & & & & & -11.0 & 9.0 & 6.0 & 38.86 & 13.05 & 3.4 \\
\hline 17 & LCV 62 & E32 (92) & $\begin{array}{l}2 \text { years and } 6-9 \\
\text { months }\end{array}$ & $\begin{array}{l}\text { Sub-Adult } \\
\text { (2) }\end{array}$ & Brown & & -14.6 & 7.3 & 1.0 & 42.71 & 13.88 & 3.5 \\
\hline 19 & LCV 72-A & T1 (95) & $\begin{array}{l}4 \text { years and } \\
9 \text { months }\end{array}$ & Adult & Brown & & -15.7 & 7.4 & 1.0 & 43.14 & 14.77 & 3.4 \\
\hline 19 & LCV 72-B & & & & & & -15.7 & 7.4 & 2.0 & 43.95 & 15.00 & 3.4 \\
\hline 19 & LCV 72-C & & & & & & -15.4 & 7.4 & 3.0 & 43.39 & 14.60 & 3.4 \\
\hline 19 & LCV 72-D & & & & & & -15.8 & 7.4 & 4.0 & 40.74 & 13.64 & 3.4 \\
\hline 19 & LCV 72-E & & & & & & -16.6 & 7.7 & 5.0 & 39.71 & 13.29 & 3.4 \\
\hline 19 & LCV 72-F & & & & & & -16.4 & 7.8 & 6.0 & 43.65 & 15.11 & 3.3 \\
\hline 19 & LCV 72-G & & & & & & -15.8 & 7.8 & 7.0 & 42.92 & 14.66 & 3.4 \\
\hline 19 & LCV 72-H & & & & & & -15.4 & 7.8 & 8.0 & 35.95 & 12.14 & 3.4 \\
\hline 19 & LCV 72-I & & & & & & -15.7 & 7.9 & 9.0 & 41.99 & 14.03 & 3.4 \\
\hline 19 & LCV 72-J & & & & & & -14.8 & 7.7 & 10.0 & 41.75 & 14.08 & 3.4 \\
\hline 20 & LCV 78-A & E1B (95) & $5-7$ years & Adult (3) & Brown & & -17.5 & 5.8 & 1.0 & 42.24 & 14.09 & 3.4 \\
\hline 20 & LCV 78-B & & & & & & -18.3 & 5.4 & 2.0 & 42.54 & 14.23 & 3.4 \\
\hline 20 & LCV 78-C & & & & & & -17.7 & 5.2 & 3.0 & 43.62 & 14.24 & 3.5 \\
\hline 20 & LCV 78-D & & & & & & -18.2 & 5.0 & 4.0 & 41.97 & 13.99 & 3.5 \\
\hline 20 & LCV 78-E & & & & & & -17.7 & 5.1 & 5.0 & 42.63 & 13.98 & 3.5 \\
\hline 21 & LCV 84 & E89 (91) & $\begin{array}{l}5 \text { years and } \\
9 \text { months- } \\
7 \text { years and } \\
6 \text { months }\end{array}$ & Adult (3) & Brown & & -14.1 & 8.2 & 1.0 & 44.44 & 14.86 & 3.4 \\
\hline 25 & LCV 101 & E18(95) & 9-11 years & Adult (4) & $\begin{array}{l}\text { Mixed beige } \\
\text { and brown }\end{array}$ & Yes & -13.4 & 7.3 & 1.0 & 42.39 & 14.02 & 3.5 \\
\hline 33 & LCV 127-A & E64 (91) & $\begin{array}{l}2 \text { years and } \\
6 \text { months- } \\
2 \text { years and } \\
9 \text { months }\end{array}$ & $\begin{array}{l}\text { Sub-Adult } \\
\text { (2) }\end{array}$ & Unknown & & -17.9 & 6.5 & 1.0 & 42.25 & 13.62 & 3.6 \\
\hline 33 & LCV 127-B & & & & & & -17.9 & 7.0 & 2.0 & 33.34 & 10.56 & 3.6 \\
\hline 33 & LCV 127-C & & & & & & -17.7 & 7.0 & 3.0 & 41.84 & 13.45 & 3.6 \\
\hline
\end{tabular}

baseline reconstructed by Szpak et al. (2013) for northern Peru.

The package SIBER (Jackson et al. 2011) and its function on standard bivariate ellipse area metrics were used for evaluating the variation in isotopic composition for bone collagen and hair keratin, at a confidence level of $40 \%$. Here, the Standard Ellipse Area corrected for small sample size $\left(\mathrm{SEA}_{\mathrm{C}}\right)$ and the Standard Ellipse Area Bayesian $\left(\mathrm{SEA}_{\mathrm{B}}\right)$ were calculated.
However, the comparisons between ellipse areas were carried out using only the $\mathrm{SEA}_{\mathrm{B}}$ posterior distribution values. The parameters used for running the Bayesian model considered $10^{4}$ iterations. Differences between ellipses were considered statistically significant when one of the ellipses was smaller or larger than the other based on the $p$-value obtained. If one ellipse area is larger than another, the $p$-value expected should be 1 or above 0.90 , whereas if one ellipse area is 
smaller than another, the $p$-value should be 0 or below 0.10 .

In order to directly compare the ellipse areas of bone collagen and hair keratin, hair carbon isotope values were adjusted to bone collagen values by an offset of 1.3\%o, following Szpak et al. (2014). In addition, for individuals with more than 1 hair section analysed, means were calculated and then included in the ellipse area estimations, together with other (non-sequentially analysed) individuals.

The Huaca Cao Viejo ellipses were compared with those computed from previous studies carried out in the north of Peru and dating to the Late Middle Horizon and LIP, namely, textile samples from Chancay and Pacatnamú (Szpak et al. 2018; Szpak, Millaire et al. 2016) and hair keratin and bone collagen samples from Huaca Santa Clara (Szpak et al. 2014). The individuals from Huaca Santa Clara are all juveniles. We are aware that comparing textile samples with our results will give only general information, at the group level. This is because the textiles could have been made from the fibres of different individuals. The textile samples do not yield information on seasonal changes or the age of the individuals from which the fibres were taken.

All these analyses were run in R: The R Project for Statistical Computing (2013).

\section{Results}

\section{Zooarchaeological Analysis: Estimation of Individual Age, Description of Pathology and Coat Colour}

We were able to arrive at an estimate of age at death for 20 out of the 32 analysed camelids (62.5\% of the total; Table 1). For the remaining 12, we were unable to reach a conclusion, because the skull had mummified or was missing and we were therefore unable to observe the teeth, or because there was a discrepancy between the age estimate based on eruption and that based on wear. The aged individuals fall into one of three main categories: 7 juveniles ( $0-2$ yrs old), 3 sub-adults (2-3 yrs old) and 10 adults (3-14+ yrs old). The adult category, which spans a wide range of ages, can be further divided into young adults (3-9 yrs old, $n=3$ ) and mature adults $(9-14+$ yrs old, $n=7)$. We were able to assign 8 of the 12 hair specimens analysed to one of the three main age categories (the thirteenth, \# 13b, having not been taken into account). Metapodia with clearly visible polydactyly were observed in 4 individuals from different age classes (Table 1; Figure 3). The individuals had either uniformly brown $(n=8)$, uniformly beige $(n$ $=5)$ (Figure 3), or mixed beige and brown $(n=10)$ (Figure 2) coats, at least on the observable anatomical parts (Table 1). Colour could not be observed for 10 individuals whose coat was no longer present.

\section{Radiocarbon Dating}

All ${ }^{14} \mathrm{C}$ dates and their calibrated ranges are presented in Table 3 and Figure 4 . The results obtained show that the deposits in the Huaca Cao Viejo date from a period comprised between cal AD 1022 and 1176 (95.4\% probability). It is noteworthy that the five samples dated show the same dates, with three of them falling in the exact same range of cal AD 1022-1150, showing that camelids were buried over a short period of time.

\section{Stable Isotope Analysis}

The results of the bone collagen and hair keratin SIA suggest good preservation for all samples analysed here, based on $\mathrm{C} / \mathrm{N}$ ratios, \%C, $\% \mathrm{~N}$ and collagen yield (wt \%) (Table 1), following the criteria of DeNiro (1985) and Ambrose (1990) for bone collagen and those of O'Connell and Hedges (1999) for hair keratin.

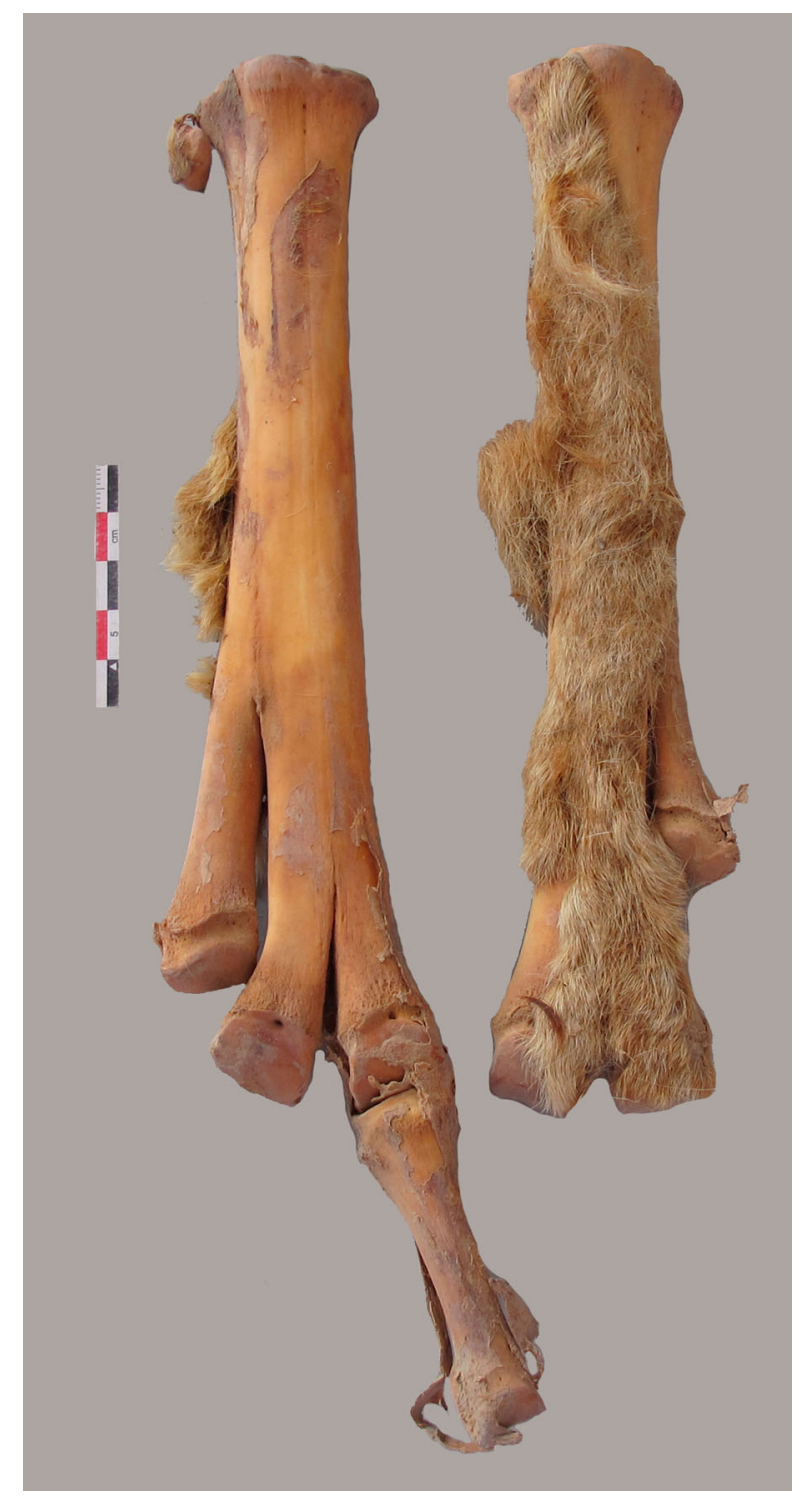

Figure 3. Photo of two metapodia belonging to a single Lambayeque camelid (Individual 18) from El Brujo showing polydactyly. The articulated phalanx and remains of the beige coat can also be observed. 
Descriptive statistics for $\delta^{13} \mathrm{C}$ and $\delta^{15} \mathrm{~N}$ in bone collagen $\left(\delta^{13} \mathrm{C}_{\text {coll }}\right.$ and $\left.\delta^{15} \mathrm{~N}_{\text {coll }}\right)$ and hair keratin $\left(\delta^{13} \mathrm{C}_{\text {ker }}\right.$ and $\delta^{15} \mathrm{~N}_{\mathrm{ker}}$ ) are presented in Table 4 , and all the data are presented in Figures 5 and 6. In Figure 6, the incremental hair sampling results are plotted by individual, as means and standard deviations, while in Figure $7(\mathrm{a}, \mathrm{b})$, intra-individual variations in $\delta^{13} \mathrm{C}_{\mathrm{ker}}$ and $\delta^{15} \mathrm{~N}_{\mathrm{ker}}$ are presented. Bone collagen $\delta^{13} \mathrm{C}_{\text {coll }}$ shows high variation, with values ranging from $16.5 \%$ to $-8.7 \%$, while $\delta^{15} \mathrm{~N}_{\text {coll }}$ shows more moderate variation, with values ranging from $+4.7 \%$ to $+9.5 \%$ o (Figure 5). Considering all incremental samples, hair keratin $\delta^{13} C_{\text {ker }}$ values also vary considerably, from $18.3 \%$ o to $-9.4 \%$ o (Figure 6), whereas $\delta^{15} \mathrm{~N}_{\mathrm{ker}}$ values vary slightly less than those for collagen, with values ranging between $+5.0 \%$ and $+9.5 \%$ (Figures 5 and 6 ).

Variability in $\delta^{13} \mathrm{C}_{\mathrm{ker}}$ and $\delta^{15} \mathrm{~N}_{\mathrm{ker}}$ values can be clearly observed at the intra- and inter-individual levels (Figures 5 and 6). In some of the camelids (such as \# 16, 19, 20 and 33), variation in $\delta^{13} \mathrm{C}_{\mathrm{ker}}$ and $\delta^{15} \mathrm{~N}_{\mathrm{ker}}$ values is rather low, while in others (\#11 and 13b), intra-individual variation is clearly observed for $\delta^{13} \mathrm{C}_{\mathrm{ker}}$ (with a range from -16.0 to $-14.1 \%$ and from -12.9 to $-9.4 \%$, respectively). There is no common pattern to the $\delta^{13} \mathrm{C}_{\mathrm{ker}}$ and $\delta^{15} \mathrm{~N}_{\mathrm{ker}}$ values at the time of death (Figure $7(\mathrm{a}, \mathrm{b})$ ). For a few of the specimens, $\delta^{13} \mathrm{C}_{\mathrm{ker}}$ values increase (\#11 and 20), whereas for others, they stay stable (\# 19 and 33) or decrease (\# 13b and

Table 3. ${ }^{14} \mathrm{C}$ dates (not calibrated and calibrated) for five camelids from Huaca Cao Viejo.

\begin{tabular}{lcccccc}
\hline Individual & $\begin{array}{c}\text { Lab } \\
\text { Number }\end{array}$ & Sample & $\begin{array}{c}{ }^{14} \mathrm{C} \\
\mathrm{yr}\end{array}$ & \pm & $\begin{array}{c}\text { From cal } \\
\text { (AD) }\end{array}$ & $\begin{array}{c}\text { To cal } \\
\text { (AD) }\end{array}$ \\
\hline 8 & $\begin{array}{c}\text { ECHo- } \\
17313 \\
11\end{array}$ & LCV 29 & 1010 & 25 & 1022 & 1150 \\
& $\begin{array}{c}\text { ECHo- } \\
17314\end{array}$ & LCV 38 & 1010 & 25 & 1022 & 1150 \\
13 & $\begin{array}{c}\text { ECHo- } \\
17315 \\
20\end{array}$ & LCV 44 & 1010 & 25 & 1022 & 1150 \\
22 & $\begin{array}{c}\text { ECHo- } \\
17316 \\
\text { ECHo- } \\
17317\end{array}$ & LCV 76 & 1000 & 25 & 1027 & 1150 \\
& LCV 88 & 970 & 25 & 1034 & 1176 \\
\hline
\end{tabular}

16) (Figure $7(\mathrm{a})$ ). Four individuals (\# 10,11,13b and 16) present cyclical variations in $\delta^{13} \mathrm{C}_{\mathrm{ker}}$ and $\delta^{15} \mathrm{~N}_{\mathrm{ker}}$ values, ranging from one cycle (\#11) to three cycles (\# 13b). The most marked variations are presented by \# 13b. Despite inter-individual difference in overall values, all individuals seem to have been culled at the highest values of the cycles. Finally, the number of cycles exhibited by the \# 13b keratin samples is not compatible with the age estimate ( 9 months to 1 year) based on the dentition of individual \# 13. This suggests that the hair and the bone do not belong to the same individual.

Intra-individual offsets in $\delta^{13} \mathrm{C}$ and $\delta^{15} \mathrm{~N}$ values between bone collagen and keratin $\left(\Delta \delta^{13} \mathrm{C}\right.$ and $\Delta \delta^{15} \mathrm{~N}$ ) for the 12 camelids are shown in Table 5. Excluding \# 13b, the $\delta^{13} \mathrm{C}$ and $\delta^{15} \mathrm{~N}$ offset values range from +0.1 to $+4.1 \%$ and from -1.3 to $+0.4 \%$, respectively. In order to be directly comparable, the keratin $\delta^{13} \mathrm{C}$ values were adjusted by $1.3 \%$ to take into account differences in tissue fractionation (Table 5). In the case of the camelids from Huaca Cao Viejo, $\delta^{13} \mathrm{C}$ offset values appear limited for most individuals. With the exception of \# 13 , they range from -1.2 to $+2.8 \%$. The youngest animals (\# 8 and 11 , both less than $1 \mathrm{yr}$ old) present almost no difference between the two tissues. Three other individuals (\# 16, 17 and 25) present negative $\Delta \delta^{13} \mathrm{C}$ values, indicating more $\mathrm{C}_{4}$ plant consumption prior to slaughter, while the remaining five individuals present positive values, indicating less consumption of $\mathrm{C}_{4}$ plants prior to slaughter. Corrected $\Delta \delta^{13} \mathrm{C}(-5.3)$ and $\Delta \delta^{15} \mathrm{~N}(-3.3)$ offset values for \# 13 (collagen) and \# 13b (hair) (Table 5) are unusual. This could be another indication that the bone and the hair belong to two different individuals or alternatively, that the individual experienced dramatic change in its diet over life. Further studies are needed in order to evaluate these two hypotheses.

We looked for isotopic variation among the individuals that could be assigned to one of the four age categories defined above (Figure 8(a,b)). No clear pattern of clustering is observed for either collagen

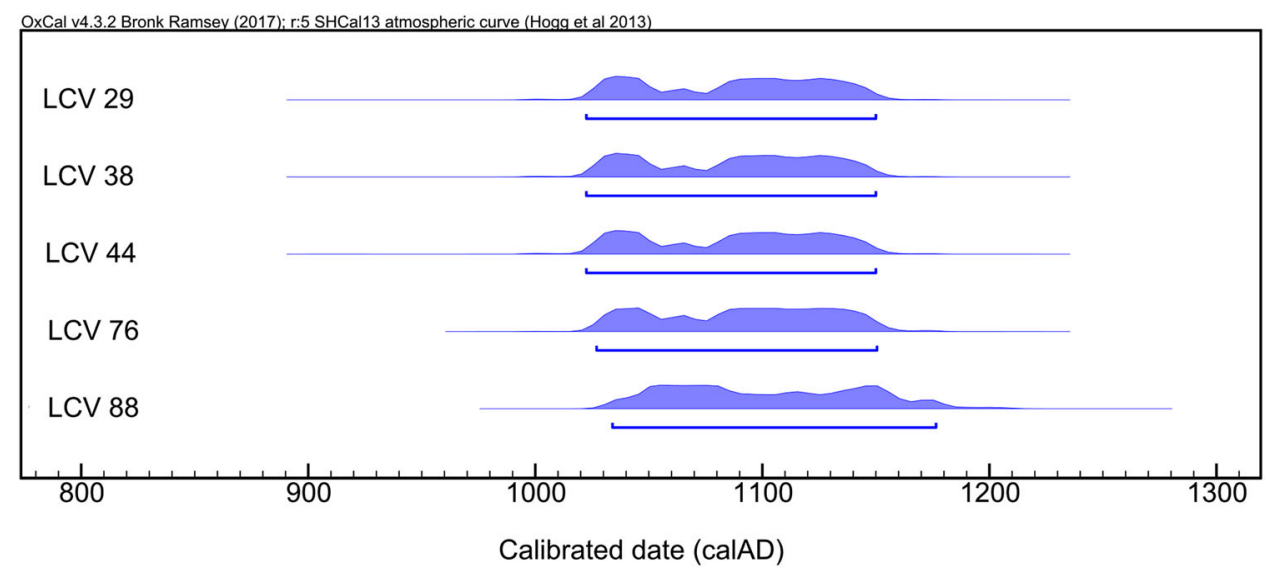

Figure 4. Calibrated radiocarbon dates for five camelids recovered from Lambayeque fardos at Huaca Cao Viejo. 
Table 4. Descriptive statistics for $\delta^{13} \mathrm{C}$ and $\delta^{15} \mathrm{~N}$ in bone collagen and hair keratin from camelids from Huaca Cao Viejo.

\begin{tabular}{|c|c|c|c|c|c|c|c|c|c|}
\hline \multirow[b]{2}{*}{ Tissue } & \multirow[b]{2}{*}{$n$ (individuals) } & \multicolumn{2}{|c|}{ Mean } & \multicolumn{2}{|c|}{ SD } & \multicolumn{2}{|c|}{ Max } & \multicolumn{2}{|c|}{ Min } \\
\hline & & $\delta^{13} \mathrm{C}$ & $\delta^{15} \mathrm{~N}$ & $\delta^{13} \mathrm{C}$ & $\delta^{15} \mathrm{~N}$ & $\delta^{13} \mathrm{C}$ & $\delta^{15} \mathrm{~N}$ & $\delta^{13} \mathrm{C}$ & $\delta^{15} \mathrm{~N}$ \\
\hline Bone collagen & 32 & -12.7 & 7.1 & 1.8 & 1.1 & -8.7 & 9.5 & -16.5 & 4.7 \\
\hline Hair keratin & 12 & -14.0 & 7.9 & 2.7 & 1.2 & -9.4 & 9.5 & -18.3 & 5.0 \\
\hline
\end{tabular}

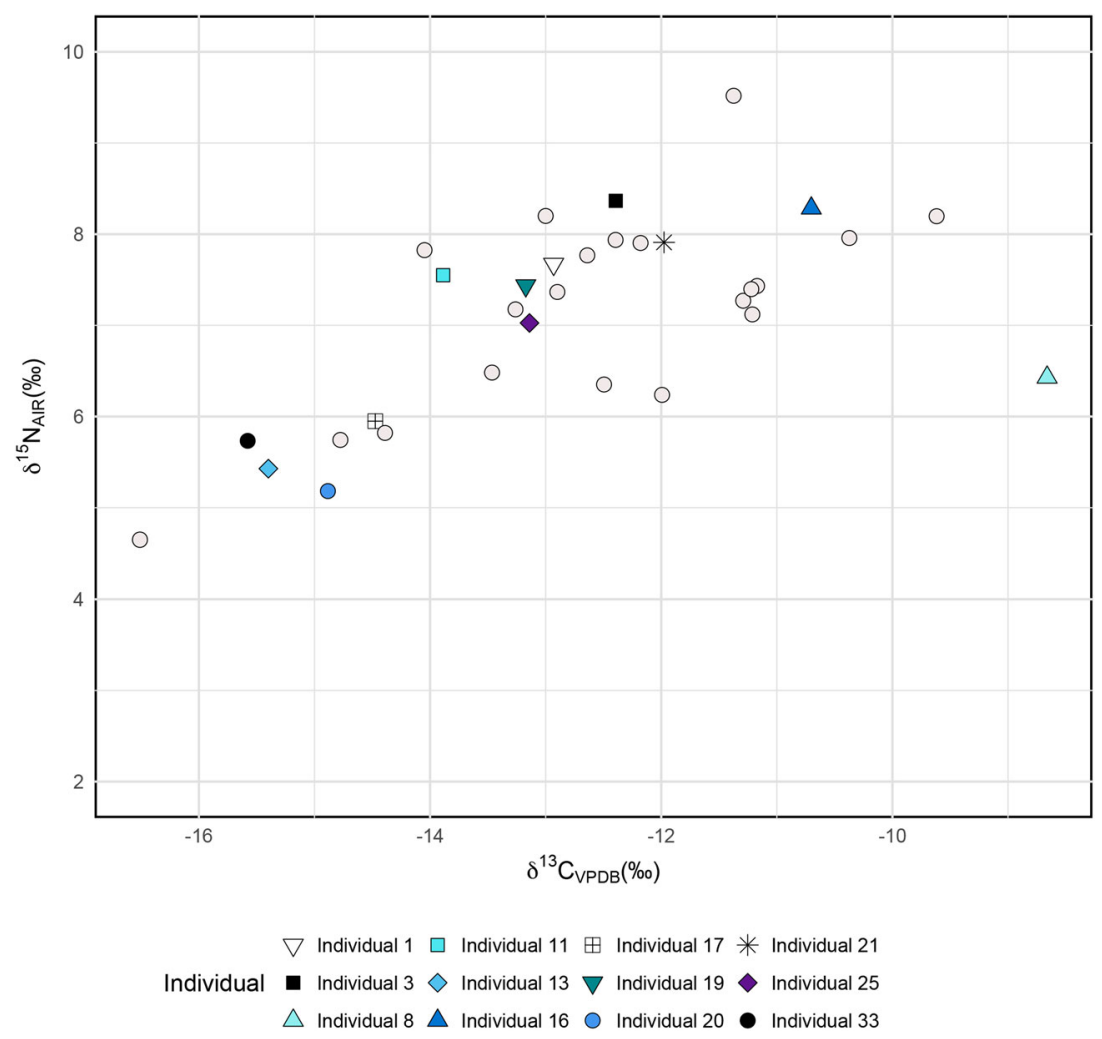

Figure 5. Bivariate plot for $\delta^{13} \mathrm{C}$ and $\delta^{15} \mathrm{~N}$ in bone collagen from Huaca Cao Viejo camelids $(n=32)$. Individuals from which hair samples were also analysed are indicated by different symbols and colours. Individuals from which no hair samples were analysed are indicated by light grey circles.

(Figure 8(a)) or keratin (Figure 8(b)). There is, however, a slight tendency for individuals in age groups 1 (0-2 yrs old) and 4 (9-14+ yrs old) to present higher $\delta^{13} \mathrm{C}_{\text {coll }}$ and $\delta^{15} \mathrm{~N}_{\text {coll }}$ values and for individuals from group 4 to show higher $\delta^{13} \mathrm{C}_{\mathrm{ker}}$ and $\delta^{15} \mathrm{~N}_{\mathrm{ker}}$ values. However, it must be noted that the hair keratin sample is much smaller than the bone collagen sample and that there were only 9 aged individuals among the 12 individuals whose hair was analysed.

Estimations of the relative contributions of $\mathrm{C}_{3}$ and $\mathrm{C}_{4}$ plants to the diet, based on Bayesian modelling analysis, are presented in Table 6 and Figure 9(a,b). The estimated means are $31.0 \% \mathrm{C}_{3}$ and $69.0 \% \mathrm{C}_{4}$ for bone collagen and $35 \% \mathrm{C}_{3}$ and $65 \% \mathrm{C}_{4}$ for hair keratin, with a 95\% credibility interval for both tissues (Figure 9(a,b)).

Ellipses comparing $\delta^{13} \mathrm{C}$ and $\delta^{15} \mathrm{~N}$ values for Huaca Cao Viejo in relation to other LIP camelid groups from the northern coast of Peru are presented in Figure 10 (a). Ellipses for the Huaca Cao Viejo collagen and hair show $\mathrm{SEA}_{\mathrm{C}}$ values of 4.9 and 7.8 , respectively (Figure 10(a)). Comparisons between groups were carried out using the $\mathrm{SEA}_{\mathrm{B}}$ sizes (Figure $10(\mathrm{~b})$ ). The ellipse size for the Huaca Cao Viejo bone collagen is significantly smaller than that for the Huaca Cao Viejo hair keratin $(p$-value $=0.926)$. The Huaca Cao Viejo bone collagen ellipse is also significantly smaller than the Huaca Santa Clara bone collagen ( $p$-value = $0.96)$ and Pacatnamú textiles $(p$-value $=0.99)$ ellipses. The Huaca Cao Viejo hair keratin ellipse is larger than the Huaca Santa Clara hair keratin and the Chancay textiles ellipses, and smaller than the Pacatnamú textiles ellipse. However, these differences are not statistically significant.

\section{Discussion}

\section{Refining the Temporal Framework for the Lambayeque Occupation of the Chicama Valley}

The set of dates presented in this study is the first for the Lambayeque period in the Chicama valley. The dates (cal. AD 1022-1176) clearly situate the Lambayeque funerary contexts of Huaca Cao Viejo during the first half of the LIP. The dates are very close to each other and suggest that the bundles and the camelids were buried over a short period of time. The dates 


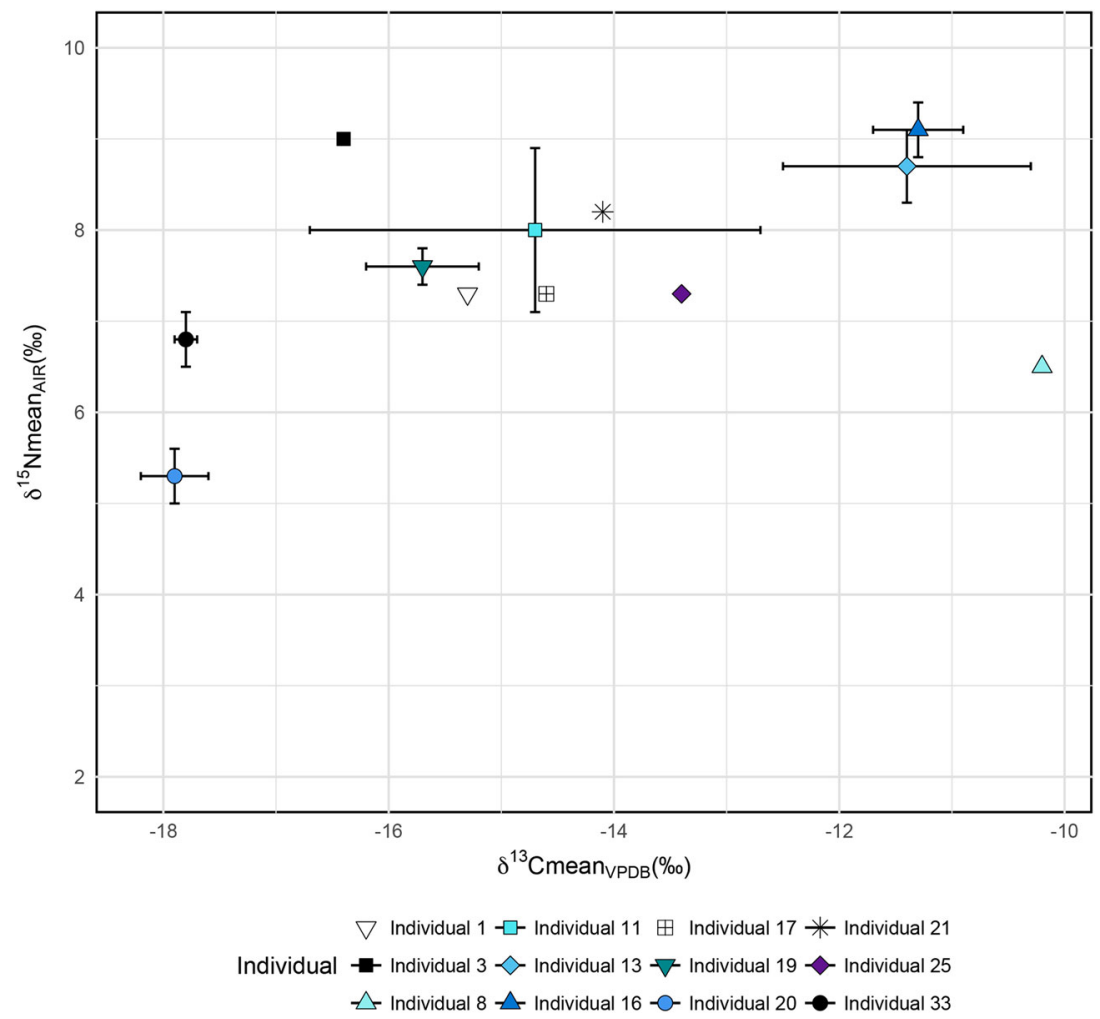

Figure 6. Bivariate plot showing $\delta^{13} \mathrm{C}$ and $\delta^{15} \mathrm{~N}$ in hair samples from Huaca Cao Viejo camelids $(n=12)$. Individuals for which incremental analyses were carried out $(n=6)$ are shown as mean values, together with their respective standard deviations.

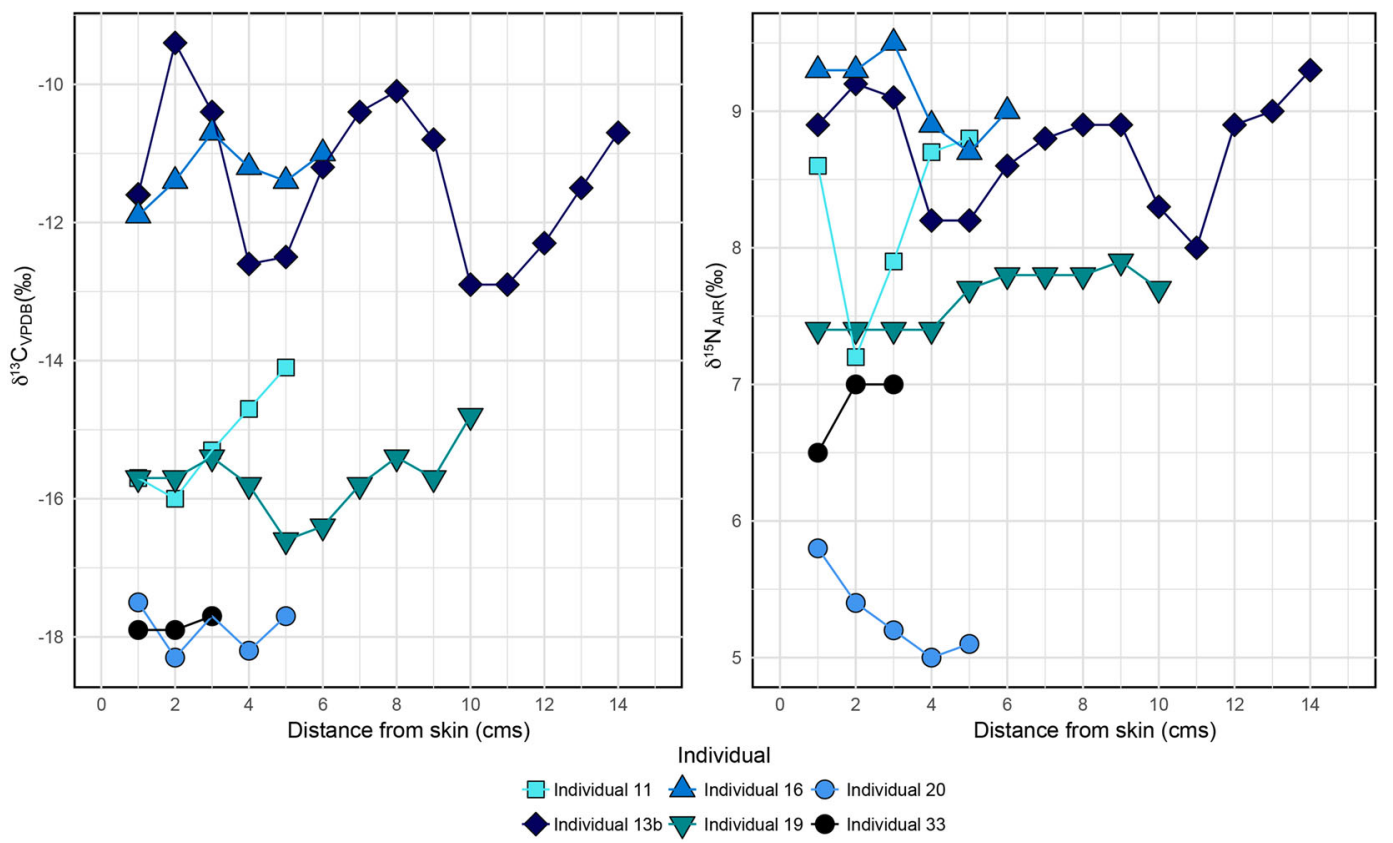

Figure 7. (a) $\delta^{13} \mathrm{C}$ keratin values for Huaca Cao Viejo camelids taken at $1 \mathrm{~cm}$ intervals starting from the root $(n=6)$. (b) $\delta^{15} \mathrm{~N}$ keratin values for Huaca Cao Viejo camelids taken at $1 \mathrm{~cm}$ intervals starting from the root $(n=6)$.

confirm the extension of the Lambayeque territory towards their northern and southern boundaries. Our radiocarbon dates, which show that the Lambayeque occupied the valley by this time, confirm Shimada's hypothesis of Lambayeque occupations circa $\mathrm{AD}$ 1000 (Shimada 2014b, 23). Our dates also provide indirect evidence that the Chimú expansion northward did not begin before the twelfth century. Our radiocarbon dataset fills an important gap for a period that lacks direct dates and chronological control, namely, the period between the end of the Mochica and Wari influences and the beginning of the Chimú Empire. 
Table 5. Intra-individual offsets in $\delta^{13} \mathrm{C}, \delta^{13} \mathrm{C}$ adjusted to bone collagen and $\delta^{15} \mathrm{~N}$ values between bone collagen and hair keratin from camelids from Huaca Cao Viejo.

\begin{tabular}{lcccr}
\hline $\begin{array}{l}\text { Individuals } \\
(\#)\end{array}$ & Burial & $\begin{array}{c}\Delta \delta^{13} \mathrm{C} \\
(\%)\end{array}$ & $\begin{array}{c}\Delta \delta^{13} \mathrm{C} \text { corrected } \\
(\% 0)\end{array}$ & $\begin{array}{c}\Delta \delta^{15} \mathrm{~N} \\
(\% 0)\end{array}$ \\
\hline 1 & E31 (92) & 2.4 & 1.1 & 0.4 \\
3 & E72 (92) & 4.1 & 2.8 & -0.6 \\
8 & E12 (92) & 1.5 & 0.2 & -0.1 \\
11 & E10 (95) & 1.3 & 0.0 & -0.7 \\
16 & E84 (91) & 0.5 & -0.8 & -0.8 \\
17 & E32 (92) & 0.1 & -1.2 & -1.3 \\
19 & T1 (95) & 2.6 & 1.3 & -0.2 \\
20 & E1B & 3.0 & 1.7 & -0.1 \\
& $(95)$ & & & \\
21 & E89 (91) & 2.1 & 0.8 & -0.3 \\
25 & E18 (95) & 0.3 & -1.0 & -0.3 \\
33 & E64 (91) & 2.3 & 1.0 & -1.1 \\
$\# 13 b$ & E77 (91) & -4.0 & -5.3 & -3.3 \\
\hline
\end{tabular}

\section{Camelids in Funerary Contexts in Northern Peru}

The 32 studied camelids associated with the Lambayeque funerary bundles represent a wide range of ages, from juveniles to mature adults, suggesting that all four age classes were considered acceptable for inclusion as funerary deposits. But does this mean that none of the age classes were preferred over the others by the officiants? Within the general category of adult (representing $50 \%$ of the sample total), large variations in age are observed. The sub-category adults over 8 yrs old (group $4=9-14+$ yrs) mainly comprises individuals in excess of 14 yrs old. Based on this variability, the data suggests no age classes were preferred. Unfortunately, there are no other studies in the Lambayeque funerary sphere with which to compare the Huaca Cao Viejo data. However our data can be compared with other contexts in the region. For the
Table 6. Estimated contributions of $C_{3}$ and $C_{4}$ sources in bone collagen and hair keratin from camelids from Huaca Cao Viejo based on Bayesian modelling using SIAR.

\begin{tabular}{lccccc}
\hline Tissue & Source & Low 95\% & High 95\% & Mode & Mean \\
\hline Bone Collagen & $C_{3}$ & 0.27 & 0.35 & 0.31 & 0.31 \\
Bone Collagen & $C_{4}$ & 0.65 & 0.73 & 0.69 & 0.69 \\
Hair Keratin & $C_{3}$ & 0.24 & 0.47 & 0.36 & 0.35 \\
Hair Keratin & $C_{4}$ & 0.53 & 0.76 & 0.64 & 0.65
\end{tabular}

Mochica, Goepfert $(2011,2012)$ showed that the juvenile age category is the most frequently represented class in burials ( $46.9 \%$ of the studied individuals), but that adults, mainly old individuals (14+yrs), are also frequently represented (34.4\%). These old camelids were deposited complete (for instance at Sipán [Goepfert 2011]), while in the Lambayeque contexts discussed here, only the skull and fore and hind limbs were deposited.

A greater contrast in age distribution appears when funerary deposits are compared with ceremonial or sacrificial ones, where the selection of just one age class (in particular juveniles less than $1 \mathrm{yr}$ old) seems to have had the preference of the officiants. This selection was documented at Santa Clara (Szpak et al. 2014), for the Virú Gallinazo period (200 BC-AD 450) and, at a larger scale, in a mass sacrifice at Huanchaquito dating to AD 1400-1450 (Goepfert et al. 2018; Goepfert and Prieto 2016), for the Chimú period. The absence of selection of particular age groups of camelids for the Lambayeque burial studied here does not mean that there was no selection at all. Information on the age at death of the humans deposited in the funerary contexts is lacking. Therefore, we cannot rule out that animals of a particular age or age class were targeted to be

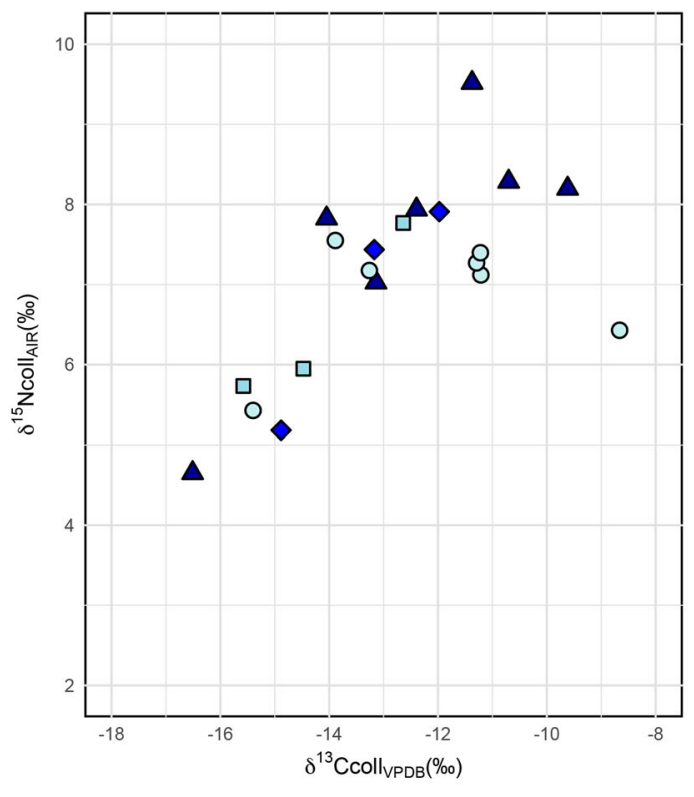

Age $\mathrm{O}$ group1 $\square$ group2 $\diamond$ group3 $\boldsymbol{\Delta}$ group4

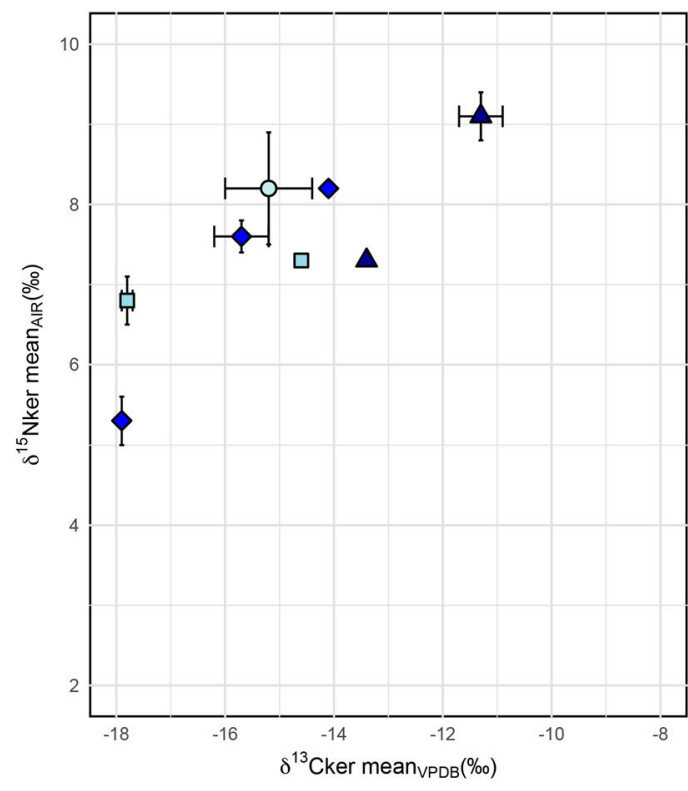

Age $\bigcirc$ group1 $\square$ - group2 $\prec$ group3 $\_$group4

Figure 8. (a) Bivariate plot showing $\delta^{13} \mathrm{C}$ and $\delta^{15} \mathrm{~N}$ values for bone collagen $(n=19)$ by age group. (b) Bivariate plot showing $\delta^{13} \mathrm{C}$ and $\delta^{15} \mathrm{~N}$ values for hair keratin $(n=8)$ by age group. Mean values and standard deviations are presented for those individuals $(n=$ 5) with incremental analysis. 
(a)

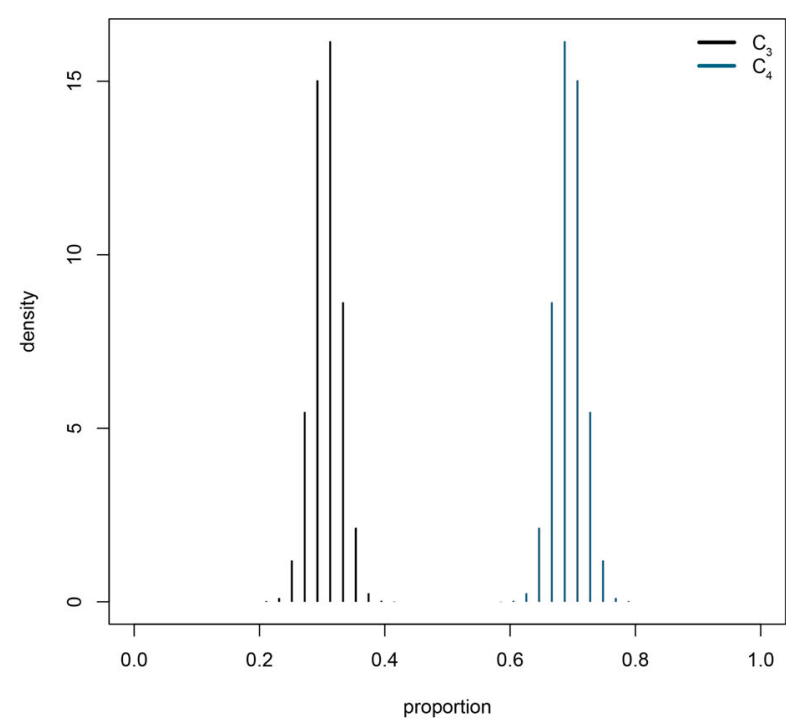

(b)

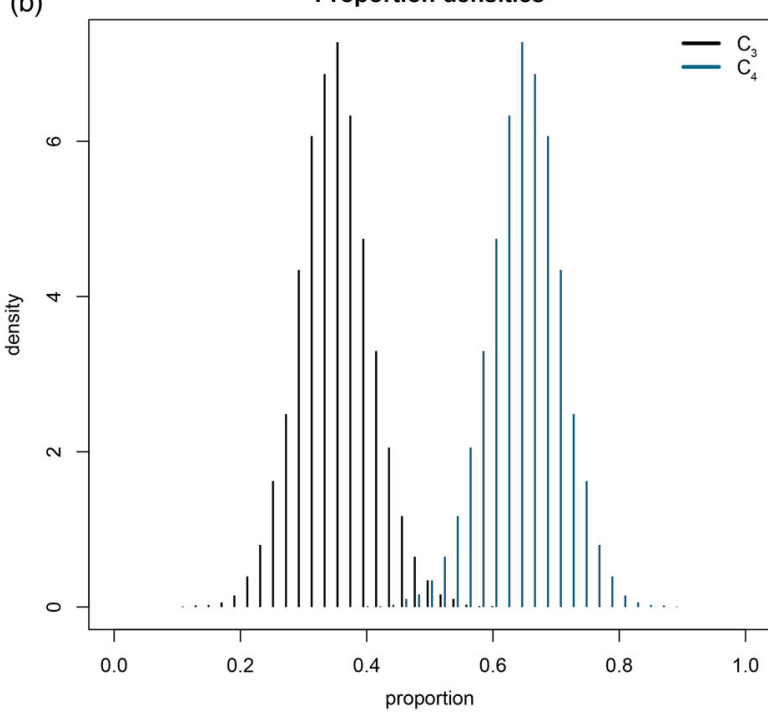

Figure 9. (a) Proportion densities of $C_{3}$ and $C_{4}$ dietary resources calculated using SIAR for bone collagen from the Huaca Cao Viejo camelids. (b) Proportion densities of $C_{3}$ and $\mathrm{C}_{4}$ resources calculated using SIAR for hair keratin from the Huaca Cao Viejo camelids. Hair keratin values were adjusted to bone collagen values by an offset of $+1.3 \%$.

buried next to a person of a particular age, age class, or gender, for instance young or adult, woman or man.

The sex and coat colour of the camelids could have been additional selection criteria. Sex has not been estimated due to an absence of reliable osteometric methods for domestic camelids. Observation of coat colour requires adequate environmental conditions for the preservation of organic remains, as was the case at Huaca Cao Viejo. However, because only certain anatomical parts were present within the bundles, the entire diversity of coat colour may not be represented in our sample. Therefore our ability to describe the coat colour at Huaca Cao Viejo remains limited. What we can say is that for the majority of the animals, the anatomical parts present show a uniform beige or brown coat or a mixed beige and brown coat. Data from recent study at Huanchaquito (Goepfert et al. 2018) indicate that coat colour may have had a greater ritual importance in northern coast ritual practices than previously thought. The study suggests that during the Chimú period at this site, coat colour and combinations of coat colour took on special importance in the choice of sacrificial victims. The taking into account of this kind of data is still new in archaeological argumentation. Coat colour and combinations of coat colour would be relevant to consider in ritual contexts, but their observation relies on the preservation quality of organic remains.

One last aspect that deserves to be underlined is the presence of supernumerary digits in the Lambayequeperiod camelids from the El Brujo complex. Polydactyly is also found in Mochica funerary contexts (Goepfert 2011), but in lower proportions. Polydactyly is interpreted by Kent, Vásquez Sánchez, and Rosales Tham (2001) and Tomczyk and Giersz (2017) as an indicator of intensification of herding and local husbandry. It has been hypothesised by Goepfert (2011) that the officiants had selected some animals with polydactyly for funerary deposits because supernumerary digits had a special symbolic meaning. Alternatively, their selection may represent an opportunistic economic and herd management practice, being a way to eliminate 'sick' animals from the herds. In killing animals with this malformation, herders reduce the risk that animals with physical problems will reproduce. This explanation may not be valid for the adult individual with polydactyly (\# 25, 9-11 yrs old), which would have had time to reproduce. Whatever the rationale, the high proportion of polydactyly in the Huaca Cao Viejo samples shows that polydactyly may have been a selection criterion for the camelids associated with the bundles.

If selection criteria existed, camelids from different origins could have been gathered in order to fulfil the ritual exigency. The presence of animals with different life histories is suggested by the inclusion of both very young and very old individuals. The fact that some of them lived longer than 14 years suggests they may have been kept not to provide meat but to provide wool or labour, as beasts of burden.

\section{Diet and Life History of the Camelids Deposited at Huaca Cao Viejo}

The camelids deposited at Huaca Cao Viejo present high $\delta^{13} \mathrm{C}$ values (bone collagen mean value $=-12.7$ $\pm 1.8 \%$; hair keratin mean value $=-14.0 \pm 2.7 \%$ o $)$ and relatively high $\delta^{15} \mathrm{~N}$ values (bone collagen mean value $=+7.1 \pm 1.1 \%$; hair keratin mean value $=+7.9 \pm$ $1.2 \%$ ). They also show large intra-group isotopic variation for $\delta^{13} \mathrm{C}$ values $(7.8 \%$ and $8.9 \%$ for bone collagen and hair keratin, respectively)) and $\delta^{15} \mathrm{~N}$ values (4.8\%o and $4.5 \%$ o for bone collagen and hair keratin, respectively), showing that these camelids had different 


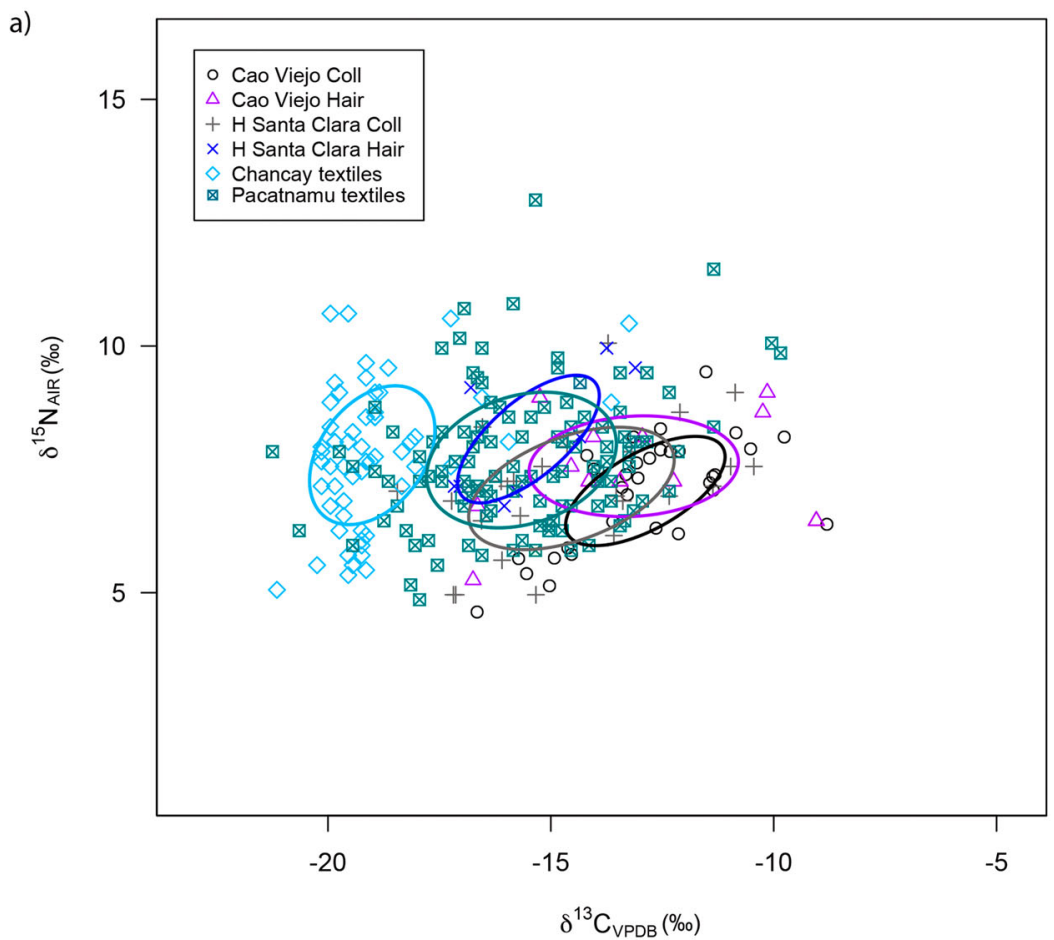

b)

SIBER ellipses on each group

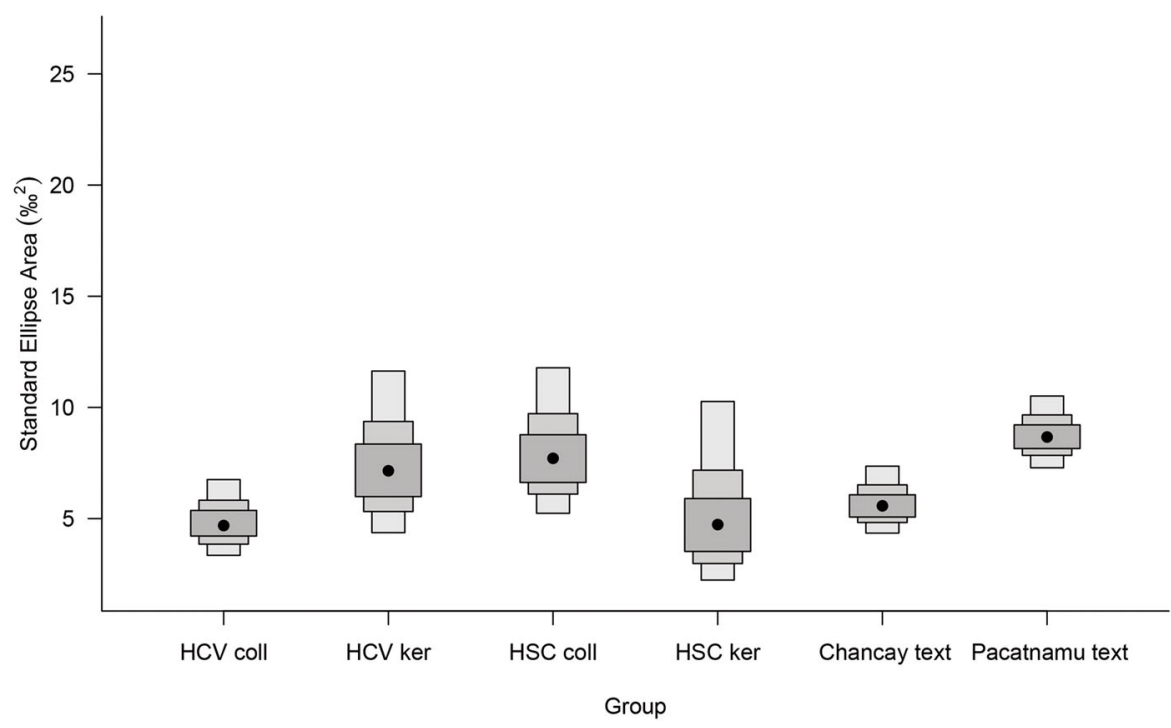

Figure 10. (a) Ellipses calculated for $\delta^{13} \mathrm{C}$ and $\delta^{15} \mathrm{~N}$ in Huaca Cao Viejo bone collagen and hair keratin samples compared with those calculated for other groups from the northern coast of Peru. (b) SIBER density plot depicting standard ellipse areas based on Bayesian analysis in each group. Shaded boxes represent the 50\%,75\% and 95\% credible intervals, from dark to light grey. Huaca Cao Viejo bone collagen (HCV coll), Huaca Cao Viejo hair keratin (HCV ker), Huaca Santa Clara bone collagen (HSC coll), Huaca Santa Clara hair keratin (HSC ker), Chancay textile (Chancay text), Pacatnamú textile (Pacatnamu text).

diets and life histories. This variation is also observed at the intra-individual level for some of the adults, suggesting changes in diet during the last years and months of life of these camelids, with some individuals consuming either more or less $\mathrm{C}_{3}$ and $\mathrm{C}_{4}$ resources, but usually less $\mathrm{C}_{4}$, at the end of their life.

High carbon and nitrogen values reported for different sites along the coast of Peru from the Preceramic to the LIP have been taken as evidence that domestic camelids were grazing on the coast and in the valleys, and not in the highlands/puna. At Chilca, in central
Peru, DeNiro (1988) explained this enrichment in ${ }^{13} \mathrm{C}$ and ${ }^{15} \mathrm{~N}$ as a consequence of marine algae consumption, while for the Osmore valley, in southern Peru, Thornton et al. (2011) suggest a possible ingestion of lomas vegetation enriched in ${ }^{15} \mathrm{~N}$, rather than of marine algae. For the northern coast of Peru, the isotopic composition of domestic camelids from the Virú, Moche, Chicama and Jequetepeque valleys also suggest the ingestion of local vegetation, both natural and cultivated (Dufour et al. 2014, 2018; Floreano Salinas 2016; Szpak et al. 2014, 2018; Szpak, Chicoine et al. 
2016; Szpak, Millaire et al. 2016; Verano and DeNiro 1993). For this area, Szpak et al. (2014) and Szpak et al. (2015) have discarded the possibility of marine algae consumption as an explanation for the high camelid $\delta^{15} \mathrm{~N}$ values, since the nitrogen isotopic composition of algae is not as enriched in ${ }^{15} \mathrm{~N}$ as that of the lomas vegetation.

At Huaca Cao Viejo, there is a high $\mathrm{C}_{4}$ input among the individuals. The Bayesian mixing model indicates mean contributions of $69.0 \%$ and $65 \%$ using the $\delta^{13} \mathrm{C}$ values of collagen and keratin, respectively. This high $\mathrm{C}_{4}$ input to the camelid diet is similar to the input observed for other coastal sites, such as Huanchaquito (Dufour et al. 2018), with a mean of $70.6 \%$, and Pacatnamú, dating to the Lambayeque period, with an estimated mean of $58 \%$ for bone collagen and $62 \%$ for hair keratin (from textiles, which, as noted above, are not a direct reflection of a particular individual diet, but probably of a group) (Szpak et al. 2018). Another site that shows similar but higher values of $\mathrm{C}_{4}$ contribution to the diet for at least some of the camelids (presumed to be alpacas) is the sierra site of Conchopata (Finucane, Maita Agurto, and Isbell 2006), in southern Peru, with a mean of $87 \%$ (proportion estimated by Szpak et al. 2018).

The high $\mathrm{C}_{4}$ contribution to the camelid diet may relate to the abundance of $\mathrm{C}_{4}$ wild plant sources in the lowlands and of the $\mathrm{C}_{4}$ domestic crop maize. Among the wild $\mathrm{C}_{4}$ plants growing along the coast, the grasses Distichlis spicata (available nearby, along the shoreline) and Eriochloa mutica appear to be good candidates for providing reliable food sources. Other $\mathrm{C}_{4}$ plants (grasses, sedges and herbs) can also be found in the lomas or at close distance, in the Andean foothills. However this wild vegetation is susceptible to water stress due to the arid conditions, and under such conditions it might present $\delta^{15} \mathrm{~N}$ values that are too high to explain the observed $\delta^{15} \mathrm{~N}$ values in the Huaca Cao Viejo camelids. On the other hand, maize, which was cultivated in the region thanks to complex irrigation systems in existence since the Mochica period (Billman 2002; Farrington and Park 1978; Hayashida 2006, among others), may also have been consumed by domestic camelids. In fact, maize foddering has been suggested for archaeological domestic camelids at Conchopata, in the Ayacucho district (Finucane, Maita Agurto, and Isbell 2006), and at Huaca Cao Viejo for the Mochica period (Dufour et al. 2014) and at Huanchaquito for the LIP (Dufour et al. 2018). It is highly probable that the maize foddering also occurred during the LIP at Huaca Cao Viejo, considering the agricultural production of the Lambayeque culture.

Camelids may thus have had access to both wild plants and maize, which would have widened their range of $\mathrm{C}_{4}$ resources. This access would be directly related to how camelids were managed by the herders (i.e. fed directly with maize, or pasturing in the valleys next to or distant from the site occupations) during the Lambayeque period. Nevertheless, the input of $\mathrm{C}_{3}$ plants is still present, and for some camelids, their hair keratin values show relatively low $\delta^{13} \mathrm{C}$ values (around $-18 \%$ ). Whether camelids were accessing $\mathrm{C}_{3}$ resources locally or were moving inland in caravan travel remains uncertain. It is difficult to distinguish between lowland and highland $\mathrm{C}_{3}$ plants based on $\delta^{13} \mathrm{C}$ values. Even though plants tend to have more elevated $\delta^{15} \mathrm{~N}$ values on the coast and in the low valleys, there are also plenty of $\mathrm{C}_{3}$ plants showing relatively low $\delta^{15} \mathrm{~N}$ in these regions, similar to the $\delta^{15} \mathrm{~N}$ of plants growing in the highlands and the puna (Szpak et al. 2013). In this sense, it is not possible to decipher whether camelids with low $\delta^{13} \mathrm{C}$ and $\delta^{15} \mathrm{~N}$ were grazing locally or moving inland.

No relation between diet age were observed in this study. The high variability described for the bone collagen and hair keratin results suggest that individuals had access to a wide range of resources, including both $\mathrm{C}_{3}$ and $\mathrm{C}_{4}$ plants, whatever their age. This suggests that the camelids were not all being fed with the same type of food. It is therefore likely that they did not all derive from the same herd, as we would expect low inter-individual variability within a single herd. Dietary variability is observed not only among individuals but also within individuals over their lifespan. First, the comparison between collagen and hair shows that some of the individuals had clearly experienced a change in their diet during their last months of life (such as \# 3 and 20). Other individuals also showed a change, albeit more limited. It is interesting to note that, as expected, there was no difference in average diet recorded by the two tissues for the two identified juveniles as they grew over the same (and short) duration of time in their lives. We did not find a general isotopic trend along hair keratin that would indicate that the individuals were fed the same diet before they were culled. This absence of a trend further supports the argument, made above based on the collagen analysis that the animals originated from different herds. Second, some of the hair samples show cyclical variations that may relate to seasonality, as shown so markedly in \# 13b (Figure $6(\mathrm{a}, \mathrm{b})$ ). The data suggest that these camelids had temporary access to certain types of resources every 2 or 4 months, either due to foddering by the herders on-site or due to the animals following some sort of mobility into different areas, containing both $\mathrm{C}_{3}$ and $\mathrm{C}_{4}$ resources, in the coastal or middle valleys.

It is worth noting that one of the main differences in the size of the ellipse was within the Huaca Cao Viejo group, between bone collagen and hair keratin, with the ellipse for bone collagen being significantly smaller (Figure 10(a)). This result could suggest that the dietary variability experienced by the individual may not be completely represented in the collagen, due to its 
slow turnover rate and the fact that bone collagen will only reflect an average of the diet over the last years of life for adult individuals (Hedges et al. 2007), hiding any possible seasonal variations that would show up in the hair keratin analysis. Alternatively, this result also suggests access to a wider variety of resources during the last months of life of the sub-adults and adults. Variability in bone collagen and hair keratin has been observed in other camelid groups dating to the EIP and LIP from the northern coast of Peru, in the Virú and Jequetepeque valleys (Szpak et al. 2014, 2018, 2015; Szpak, Chicoine et al. 2016). However, incremental analysis on hair keratin from Huaca Santa Clara and Huancaco, in the Virú valley, did not show such a strong cyclical pattern in their compositions (Szpak et al. 2014; Szpak, Millaire et al. 2016).

\section{Local Herding During the Lambayeque Occupation at Huaca Cao Viejo}

Despite the high intra-group variation observed in the data, the generally high $\delta^{13} \mathrm{C}$ values observed for Huaca Cao Viejo strongly suggest that the geographic origin for the majority of these camelids was the lowlands or coast rather than the highlands or puna. Based on the high contribution of $\mathrm{C}_{4}$ plants, it is highly likely that camelids were either grazing or foddering locally.

As previously mentioned, three individuals showed relatively low $\delta^{13} \mathrm{C}_{\mathrm{ker}}(<-18 \%)$ and $\delta^{15} \mathrm{~N}_{\mathrm{ker}}(<$ $+5 \%$ ) values. It is not clear whether these individuals consumed local plants depleted in ${ }^{13} \mathrm{C}$ and ${ }^{15} \mathrm{~N}$ or, instead, travelled to different regions, i.e. the highlands, where $\mathrm{C}_{3}$ plants with low $\delta^{15} \mathrm{~N}$ values are common. If they moved and travelled, it is possible they could have been used in caravan activities. The individuals showing the lowest $\delta^{13} \mathrm{C}_{\mathrm{ker}}$ values are one sub-adult (\# 33) and two adults (\# 19 and 20). Their ages would have allowed them to be enrolled in caravans (Nielsen 2009). It is remarkable that two (\#19 and 20) of these three individuals do not show the low bone collagen values that are characteristic of the rest of the group. This suggests that these two camelids originated from the coast and subsequently consumed $\mathrm{C}_{4}$ resources locally; their movements to sites with plants depleted in ${ }^{13} \mathrm{C}$ and ${ }^{15} \mathrm{~N}$ were probably seasonal and/ or were only initiated during the last months of life. Seasonality can be an important component of pastoralism. The existence of seasonal pastoral activity on the coast would need to be tested using mobility markers, such as stable oxygen or radiogenic strontium isotopes. Other sites from the northern coast of Peru, such as Huaca Santa Clara, Pacatnamú, Huanchaquito and Huancaco, as well as the Mochica component of the El Brujo complex, also show a local origin for camelids (Dufour et al. 2014, 2018; Goepfert et al. 2013; Szpak et al. 2014; Szpak, Millaire et al. 2016). Local herding activities have been proposed for these sites. However, this was not the case for the camelids that provided the wool for Chancay textiles, which show quite consistently low $\delta^{13} \mathrm{C}$ values, suggesting a highland origin (Szpak et al. 2015).

The Huaca Cao Viejo bone collagen ellipse is smaller than the Huaca Santa Clara collagen ellipse and the Pacatnamú textiles ellipse (Figure 10(a)). This evidence suggests a different niche width for the camelids from Huaca Santa Clara and Pacatnamú, with those individuals probably having access to a wider range of resources than did the Huaca Cao Viejo camelids. What are the reasons behind the different width of the camelid niche from Huaca Cao Viejo? And how might we explain the variability observed in the $\delta^{13} \mathrm{C}$ and $\delta^{15} \mathrm{~N}$ at the individual level? How do these aspects relate to camelid management during the Lambayeque period?

The information obtained so far in Huaca Cao Viejo tells us about complex individual and group variation for camelids herded at the coastal and lowland sites. Szpak et al. (2014) proposed that herding may have occurred at a small scale, organised at the family or kin levels, on the northern coast of Peru. These practices may have started for Huaca Gallinazo and Huaca Santa Clara, in the Virú valley, during the Early Intermediate Period (200 BC-AD 600) and would have continued through time, as shown by the high variability in isotopic results obtained on bone collagen of sacrificed camelids dating to $\mathrm{MH}$ at Huancaco (Szpak, Millaire et al. 2016) and to the LIP at Huaca Santa Clara (Szpak et al. 2014), as well as for textiles from Pacatnamú (Szpak et al. 2018). In this sense, no temporal change in herding practices is suggested for the Virú valley.

In contrast to the cultural groups that occupied the Virú valley from the Early Horizon to the LIP, the Lambayeque culture extended over a large territory, marked by the implantation of important sites composed of one or multiple truncated pyramids, platforms with multiple levels, and craftwork and domestic sectors. The Huaca Loro burials (Shimada 1995) and the recently discoveries at Chotuna-Chornancap (Wester La Torre 2016) suggest the marked levels in social status characteristic of a hierarchical society. High-status cultural markers, such as ceramics or metal, extend outside the nuclear centres localised in the Lambayeque valley, showing the great administrative, political and economic control exerted over the population.

Camelids also played an essential role, in particular in the circulation and trade in goods over long distances. In this sense, it is difficult to compare the variation and proposed small-scale herding practices observed in the Virú Valley with what was going on in the Lambayeque culture. The structure of the society, as well as the type and organisation of the sites, were totally different, and camelids were probably managed in a different way and at a different level. It 
may not be possible to assume that Lambayeque political organisation achieved a state level, but it was arguably more comparable to that of the Chimú empire than to that of the Virú-Gallinazo society. More developed trading, especially for prestigious craftwork goods, was necessary (Shimada 1982, 1995; Wester La Torre 2016). Although the Lambayeque craftwork was no more sumptuous than that of earlier times, it required more exogenous goods (such as Spondylus princeps, among others) and therefore more exchange with other valleys and other parts of the Pacific coast, in addition to exchange with the highlands. These growing needs probably required more caravans, more animals, and, as a consequence, intensification of camelid herding.

\section{Conclusions}

This study highlights the high diversity in management practices and diet for the camelids buried at Huaca Cao Viejo during the beginning of the LIP (cal. AD 10221176). This is evidenced by the wide range of camelid ages and proportion of $\mathrm{C}_{3}$ vs. $\mathrm{C}_{4}$ food in their diet. In order to better understand this diversity during the LIP in El Brujo Complex, further studies, involving the application of stable oxygen isotopes and radiogenic strontium isotopes, are needed in order to evaluate, corroborate and complement the information presented here on their geographic origins. The combination of age, physical characteristics and stable isotopic composition of the camelids give us insights into the complexity and diversity of pre-Hispanic funerary practises. Coat colour and the presence of congenital malformation (polydactyly) may have been important in the choice of animals that accompanied the deceased. Furthermore, the diversity in camelid management and origins raises questions about the social and economic organisation of the Lambayeque society in general and that of the population that occupied the Chicama Valley during the first half of the LIP in particular.

\section{Acknowledgments}

We thank Olivier Tombret (UMR 7209 and Labex BcDiv, Muséum national d'Histoire naturelle, France) for technical assistance in the lab, Denis Fiorillo (Service de Spectrométrie de Masse Isotopique du Muséum, Muséum national d'Histoire naturelle, France) for the stable isotope analysis, Caroline Gauthier and FrançoisThil (LSCE, Gif-sur-Yvette) for their help with the radiocarbon measurements We also thank Arabel Fernández (Complejo Arqueológico El Brujo, Peru) for her assistance with the camelid material at Museo of Huaca Cao and Belkys Gutiérrez Léon (BGL Arqueologia, Peru) for her administrative help. We also thank Claudio Quezada for his help with SIBER and Suzanne Needs-Howarth for improving the quality of the English writing.

\section{Disclosure statement}

No potential conflict of interest was reported by the authors.

\section{Funding}

This work was supported by the ANR CAMELANDES under [grant number ANR-15-CE27-0002-01].

\section{Notes on contributors}

Francisca Santana-Sagredo is a FONDECYT Postdoctoral Researcher at the Universidad de Antofagasta, Chile. She is a bioanthropologist and bioarchaeologist interested in the application of stable isotope analysis and radiocarbon dating for studying Pre-Columbian societies in the Andes, in particular Agro-Pastoral groups from the Atacama Desert. She is a former Postdoctoral Researcher in the project "CAMELANDES - Pre-Hispanic societies facing their environment: spatial and diachronic change in Andean pastoralism (1001470 AD)".

Elise Dufour is an associate professor at the Muséum national d'Histoire naturelle in Paris. Her research deals with the relationship between humans and animals during the Holocene. She uses stable isotopes measured on different archaeological archives, such as bones, teeth and otoliths. In collaboration with Nicolas Geopfert (investigator at the CNRS) is currently involved in a program entitled Pre-Hispanic societies facing their environment: spatial and diachronic change in Andean pastoralism (100-1470 AD) "CAMELANDES" that studies pastoralism on the northern coast of Peru. The CAMELANDES project aims to bring new data on the adaptation to the coast of the complex pre-Hispanic human societies of Northern Peru. Stable isotope analysis (carbon, nitrogen, oxygen and strontium) performed by Elise Dufour highlights. The complexity of and diversity in pastoral practices in the Mochica, Lambayeque and Chimú cultures (Life History and Origin of the Camelids Provisioning a Mass Killing Sacrifice During the Chimú Period: Insight from Stable Isotopes, Environmental Archaeology, 2018).

Nicolas Goepfert is an investigator at the CNRS (the French national centre for scientific research). He is an archaeologist and zooarchaeologist specializing in the northern coast of Peru. His research deals with funerary and sacrificial practices linked to animals, especially South American camelids, and the adaptation of human and animals to the desert Pacific coast of Peru. He has published several articles on the topic, and he is co-editor, with S. Vásquez, C. Clément and A. Christol, of Las sociedades andinas frente a los cambios pasados y actuales: dinámicas territoriales, crisis, fronteras y movilidades (IFEA-LabEx DynamiTe-UNT, 2016).

Antoine Zazzo is a senior researcher at CNRS (the French national centre for scientific research). He is a bioarcheologist and a geochemist specialized in stable isotope analysis and radiocarbon dating of animal and human remains, in relation to modern and ancient herding practices. He works in different parts of the world, including Peru, the Arabic Peninsula and Mongolia.

Régulo Franco Jordán is an archaeologist and was director of the archaeological investigations at the Templo Viejo of Pachacámac between 1986-1990. He is currently the founder director of the Archaeological Program El Brujo Complex and Cao Museum (1990-2018). He is author of numerous 
research articles and books about his research on the central and northern coast of Peru, in particular about the Mochica Culture.

Segundo Vásquez Sánchez is a Professor of Archaeology in the Social Sciences Faculty of the Universidad Nacional de Trujillo (UNT). His research areas are focused in the Formative Period of Peru, the Initial Period ceramics, and the Mochica Culture. He was founder director of the Archaeological Program El Brujo Complex between 1990 and 2007, and he is currently the director of the Archaeological Project Cerro Santa Ana. He has published several articles, and he is co-editor, with N. Goepfert, C. Clément and A. Christol, of Las sociedades andinas frente a los cambios pasados y actuales: dinámicas territoriales, crisis, fronteras y movilidades (IFEALabEx DynamiTe-UNT, 2016).

\section{ORCID}

Elise Dufour (iD http://orcid.org/0000-0001-8865-7055

Nicolas Goepfert (D) http://orcid.org/0000-0002-6155-1856

\section{References}

Ambrose, S. 1990. "Preparation and Characterization of Bone and Tooth Collagen for Isotopic Analysis." Journal of Archeological Science 17: 431-451.

Billman, B. R. 2002. "Irrigation and the Origins of the Southern Moche State on the North Coast of Peru." Latin American Antiquity 13 (4): 371-400.

Bird, J., J. Hyslop, and M. D. Skinner. 1985. The Preceramic Excavations at the Huaca Prieta, Chicama Valley, Peru. Anthropological Papers of the American Museum of Natural History 62 (1). New York: American Museum of Natural History.

Bonavia, D. 1996. Los camélidos Sudamericanos: Una introducción a su estudio. Travaux de l'Institut Français d'Études Andines (IFEA), Tome 93. Lima: IFEA-UPCHConservación Internacional.

Bronck Ramsey, C., and S. Lee. 2013. "Recent and Planned Developments of the Program OxCal." Radiocarbon 55: 720-730.

Capriles, J. M., and N. Tripcevich. 2016. The Archaeology of Andean Pastoralism. Albuquerque: University of Mexico Press.

DeNiro, M. J. 1985. "Postmortem Preservation and Alteration of in Vivo Bone Collagen Isotope Ratios in Relation to Palaeodietary Reconstruction." Nature 317: 806-809.

DeNiro, M. J. 1988. "Marine Food Sources of Prehistoric Coastal Peruvian Camelids: Isotopic Evidence and Implications." In Economic Prehistory of the Central Andes, edited by E. S. Wing and J. C. Wheeler, 119-129. Oxford: BAR International Series.

Dillehay, T. D. 2017. Where the Land Meets the Sea: Fourteen Millennia of Human History at Huaca Prieta, Peru. Austin: University of Texas Press.

Dufour, E., N. Goepfert, L. B. Gutiérrez, C. Chachat, R. Franco Jordán, and S. V. Sánchez. 2014. "Pastoralism in Northern Peru During Pre-Hispanic Times: Insights from the Mochica Period (100-800 AD) Based on Stable Isotopic Analysis of Domestic Camelids." Plos One 9 (1): e87559.

Dufour, E., N. Goepfert, M. Le Neün, G. Prieto, and J. Verano. 2018. "Life History and Origin of the Camelids
Provisioning as Mass Killing Sacrifice During the Chimú Period: Insight from Stable Isotopes." Environmental Archaeology. doi:10.1080/14614103.2018.1498165.

Ebinger, J. E., D. Seigler, and H. D. Clarke. 2000. “Taxonomic Revision of South American Species of the Genus Acacia Subgenus Acacia (Fabaceae: Mimosoidae)." Systematic Botany 25 (4): 588-617.

Ehleringer, J. R., P. W. Rundel, B. Palma, and H. Mooney. 1998. "Carbon Isotope Ratios of Atacama Desert Plants Reflect Hyperaridity of Region in Northern Chile." Revista Chilena de Historia Natural 71: 79-86.

Farquhar, G. D., J. R. Ehleringer, and K. T. Hubick. 1989. "Carbon Isotope Discrimination and Photosynthesis." Annual Review of Plant Physiology and Plant Molecular Biology 40: 503-537.

Farrington, I. S., and C. C. Park. 1978. "Hydraulic Engineering and Irrigation Agriculture in the Moche Valley, Peru: C. A.D. 1250-1532." Journal of Archaeological Science 5: 255-268.

Fernández, J., and H. O. Panarello. 1999-2001. "Isótopos del carbono en la dieta de herbívoros y carnívoros de los Andes jujeños.” Xama 12-14: 71-85.

Fernández Alvarado, J. C., and C. Wester La Torre, eds. 2014. Cultura Lambayeque en el contexto de la costa norte del Perú. Chiclayo: EMDECOSEGE.

Finucane, B., P. Maita Agurto, and W. H. Isbell. 2006. "Human and Animal Diet at Conchopata, Peru: Stable Isotope Evidence for Maize Agriculture and Animal Management Practices During the Middle Horizon." Journal of Archaeological Science 33: 1766-1776.

Floreano Salinas, D. 2016. "Estudios isotópicos para establecer la dieta de los camélidos en la ocupación post Moche en Plaza 1, Huaca de la Luna, Trujillo-Perú.” Archaeobios 10: 5-36.

Flores Ochoa, J., K. MacQuarrie, and J. Portus, eds. 1994. Oro de los Andes: Las llamas, alpacas, vicuñas y guanacos de Sudamérica. Barcelona: Jordi Blassi.

Franco Jordán, R., and C. Gálvez Mora. 2005. "Muerte, identidades y prácticas funerarias post Mochicas en el complejo El Brujo, valle de Chicama, costa norte del Perú." In Muerte y Evidencias Funerarias en los Andes Centrales: Avances y Perspectivas, edited by C. C. Olaya and M. A. Romero Bernales, 79-118. Corrientes Arqueológica 1. Lima: Universidad Nacional Federico Villareal.

Franco Jordán, R., and C. Gálvez Mora. 2014. "Contextos funerarios de transición y Lambayeque en el complejo El Brujo, valle Chicama." In Cultura Lambayeque en el contexto de la costa norte del Perú, edited by J. C. Fernández Alvarado and C. Wester La Torre, 139-165. Chiclayo: EMDECOSEGE.

Franco Jordán, R., C. Gálvez Mora, and S. Vásquez Sánchez. 2005. El Brujo: Pasado milenario. Trujillo: Ediciones Sian.

Franco Jordán, R., C. Gálvez Mora, and S. Vásquez Sánchez. 2007. El Brujo: Prácticas funerarias post Mochicas. Lima: Fundación Augusto N. Wiese.

Goepfert, N. 2011. Frayer la route d'un monde inversé: Sacrifice et offrandes animales dans la culture Mochica (100-800 apr. J.C.), côte nord du Pérou. Paris Monographs in American Archaeology 28. British Archaeological Reports International Series 2278. Oxford: British Archaeological Reports.

Goepfert, N. 2012. "New Zooarchaeological and Funerary Perspectives on Mochica Culture (100-800 A.D.), Peru." Journal of Field Archaeology 37 (2): 104-120.

Goepfert, N., E. Dufour, B. Gutiérrez, and C. Chauchat. 2013. "Origen geográfico de camélidos en el periodo Mochica 
(100-800 AD) y análisis isotópico secuencial del esmalte dentario: Enfoque metodológico y aportes preliminares." Bulletin de l'Institut Français d'Etudes Andines 42: 25-48.

Goepfert, N., E. Dufour, G. Prieto, and J. W. Verano. 2018. "Herds for the Gods? Selection Criteria and Herd Management at the Massive Sacrifice Site of Huanchaquito-Las Llamas During the Chimú Period, Northern Coast of Peru." Environmental Archaeology. doi:10.1080/14614103.2018.1541956.

Goepfert, N., and G. Prieto. 2016. "Offering Llamas to the Sea: The Economic and Ideological Importance of Camelids in the Chimu Society, North Coast of Peru." In The Archaeology of Andean Pastoralism, edited by J. M. Capriles and N. Tripcevich, 197-210. Albuquerque: New Mexico Press.

Hayashida, F. 2006. "The Pampa de Chaparrí: Water, Land, and Politics on the North Coast of Peru." Latin American Antiquity 17: 243-263.

Heaton, T. H. E. 1987. "The $15 \mathrm{~N} / 14 \mathrm{~N}$ Ratios of Plants in South Africa and Namibia: Relationship to Climate and Coastal/Saline Environments." Oecologia 74: 236-246.

Hedges, R. E. M., J. G. Clement, C. D. L. Thomas, and T. C. O'Connell. 2007. “Collagen Turnover in the Adult Femoral Midshaft: Modeled from Anthropogenic Radiocarbon Tracer Measurements." American Journal of Physical Anthropology 133: 808-816.

Hogg, A. G., P. G. Blackwell, M. Niu, C. E. Buck, T. P. Guilderson, T. J. Heaton, J. G. Palmer, et al. 2013. "SHCal13 Southern Hemisphere Calibration, 050.000 Years cal BP.” Radiocarbon 55: 115-126.

Jackson, A. L., R. Inger, A. C. Parnell, and S. Bearhop. 2011. "Comparing Isotopic Niche Widths among and within Communities: SIBER Stable Isotope Bayesian Ellipses in R.” Journal of Animal Ecology 80: 595-602.

Jones, R. J., M. M. Ludlow, J. H. Troughton, and C. D. Blunt. 1981. "Changes in the Natural Carbon Isotope Ratios of the Hair from Steers Fed Diets of C4, C3 and C4 Species in Sequence." Search 12: 85-87.

Kent, J. D., V. F. Vásquez Sánchez, and T. E. Rosales Tham. 2001. "Pastoreo y manejo de camélidos en la época Lambayeque: Datos zooarqueológicos." In El uso de los camélidos a través el tiempo, edited by G. L. Mengoni Goñalons, D. E. Olivera, and H. D. Yacobaccio, 131144. Buenos Aires: Ediciones del Tridente-GZCICAZ.

Knudson, K. J. 2014. "La migración en la cultura Sicán: Análisis del movimiento poblacional en el pasado usando la geología y la química." In Cultura Sicán: Esplendor preincaico en la costa norte, edited by I. Shimada, 283-191. Lima: Fondo Editorial del Congreso del Perú.

Longin, R. 1971. "New Method of Collagen Extraction for Radiocarbon Dating.” Nature 230: 241-242.

Lozada, M. C., J. E. Buikstra, G. Rakita, and J. Wheeler. 2009. "Camelid Herders: The Forgotten Specialists in the Coastal Señorío of Chiribaya, Southern Peru." In Andean Civilization: A Tribute to Michael E. Moseley, edited by J. Marcus and P. R. Williams, 351-364. Los Angeles: Cotsen Institute of Archaeology. Monograph 63.

Maldonado-Fonkén, M. S. 2014-2015. "An Introduction to the Bofedales of the Peruvian High Andes." Mires and Peat 15: 1-13.

Moore, J. D., and C. J. Mackey. 2008. “The Chimú Empire.” In The Handbook of South American Archaeology, edited by H. Silverman, and W. H. Isbell, 783-807. New York: Springer.

Mostacero, J., and F. Mejía. 1993. Taxonomía de Fanerógamas Peruanas. Lima: Consejo Nacional de Ciencia, Tecnología e Innovación Tecnológica.
Mujica Barreda, E., R. Franco Jordan, C. Gálvez Mora, J. Quilter, A. Murga Cruz, C. Gamarra de la Cruz, V. H. Ríos Cisneros, S. Lozada Alcade, J. W. Verano, and M. Aveggio Merello. 2007. El Brujo: Huaca Cao, centro ceremonial Moche en el valle de Chicama. Lima: Fundación Augusto N. Wiese.

Murra, J. V. 1972. El 'control vertical' de un máximo de pisos ecológicos en la economía de las sociedades Andinas. Huanuco: Universidad Hermilio Valdizan.

Murra, J. V. 1985. "The Limits and Limitations of the 'Vertical Archipelago' in the Andes." In Andean Ecology and Civilization: An Interdisciplinary Perspective of Andean Ecological Complementarity, edited by S. Masuda, I. Shimada, and C. Morris, 15-20. Tokyo: University of Tokyo Press.

Narváez, A., and B. Delgado. 2011. Huaca las Balsas de Túcume: Arte Mural Lambayeque. Lima: Fundación Augusto N. Wiese.

Nielsen, A. 2009. "Pastoralism and the Non-Pastoralism World in the Late Pre-Columbian History of the Southern Andes (1000-1535)." Nomadic Peoples 13: 1735.

O’Connell, T. C., and R. E. M. Hedges. 1999. "Isotopic Comparison of Hair and Bone: Archaeological Analyses." Journal of Archaeological Science 26: 661665.

O’Connell, T. C., R. E. M. Hedges, M. A. Healy, and A. H. R. W. Simpson. 2001. "Isotopic Comparison of Hair, Nail and Bone: Modern Analysis." Journal of Archaeological Science 28: 1247-1255.

Parnell, A. C., R. Inger, S. Bearhop, and A. L. Jackson. 2010. "Source Partitioning Using Stable Isotopes: Coping with too Much Variation.” Plos One 5: e9672.

Prieto Burmester, O. G. 2014. "El fenómeno Lambayeque en San José de Moro, valle de Jequetepeque: Una perspectiva desde el valle vecino." In Cultura Lambayeque: En el contexto de la costa norte del Perú, edited by J. C. Fernández Alvarado and C. Wester La Torre, 107-137. Chiclayo: EMDECOSEGE.

R Core Team. 2013. R: A Language and Environment for Statistical Computing. Vienna: $\mathrm{R}$ Foundation for Statistical Computing. http://www.R-project.org/.

Rundel, P. W., M. O. Dillon, B. Palma, H. A. Mooney, S. L. Gulmor, and J. R. Ehleringer. 1991. "The Phytogeography and Ecology of the Coastal Atacama and Peruvian Deserts." Aliso: A Journal of Systematic and Evolutionary Botany 13: 1-49.

Shimada, I. 1981. "The Batan Grande-La Leche Archaeological Project: The First Two Seasons." Journal of Field Archaeology 8: 405-446.

Shimada, I. 1982. "Horizontal Archipelago and CoastHighland Interaction in North Peru: Archaeological Models." In Senri Ethnological Studies, edited by L. Millones and T. Hiroyasu, 137-208. Senri Ethnological Studies 10. Suita: Museo Nacional de Etnologia.

Shimada, I. 1995. Cultura Sicán: Dios, riqueza y poder en la costa norte del Perú. Lima: Banco Continental.

Shimada, I. 2014a. Cultura Sicán: Esplendor Preincaico en la costa norte. Lima: Fondo Editorial del Congreso del Perú.

Shimada, I. 2014b. "Detrás de la Máscara de Oro: La cultura Sicán.” In Cultura Sicán: Esplendor Preincaico en la costa norte, edited by I. Shimada, 15-90. Lima: Fondo Editorial del Congreso del Perú.

Shimada, M., and I. Shimada. 1985. "Prehistoric Llama Breeding and Herding on the North Coast of Peru." American Antiquity 50: 3-26. 
Szpak, P., D. Chicoine, J.-F. Millaire, C. D. White, R. Parry, and F. J. Longstaffe. 2016. "Early Horizon Camelid Management Practices in the Nepeña Valley, North-Central Coast of Peru." Environmental Archaeology 21: 230-245.

Szpak, P., J.-F. Millaire, C. B. Donnan, and F. J. Longstaffe. 2018. "Stable Isotope Sourcing of Wool from Textiles at Pacatnamú.” Archaeometry 60: 612-627.

Szpak, P., J.-F. Millaire, C. D. White, S. Bourget, and F. J. Longstaffe. 2016. "Life Histories of Sacrificed Camelids from Huancaco (Virú Valley)." In Reconstructing Sacrifice on the North Coast of Peru: Archaeological Studies of Ritual Violence in the Ancient Andes, edited by H. D. Klaus and J. M. Toyne, 319-341. Austin: University of Texas Press.

Szpak, P., J.-F. Millaire, C. D. White, G. F. Lau, F. Surette, and F. J. Longstaffe. 2015. "Origins of Prehispanic Camelid Wool Textiles from the North and Central Coasts of Peru Traced by Carbon and Nitrogen Isotopic Analyses." Current Anthropology 56: 449-459.

Szpak, P., J.-F. Millaire, C. White, and F. J. Longstaffe. 2014. "Small Scale Camelid Husbandry on the North Coast of Peru (Virú Valley): Insight from Stable Isotope Analysis." Journal of Anthropological Archaeology 36: 110-129.

Szpak, P., C. White, F. J. Longstaffe, J.-F. Millaire, V. F. Vásquez Sánchez, and John P. Hart. 2013. "Carbon and Nitrogen Isotopic Survey of Northern Peruvian Plants: Baselines for Paleodietary and Paleoecological Studies." Plos One 8: e53763.

Thornton, E. K., S. D. Defrance, J. Krigbaum, and P. R. Williams. 2011. "Isotopic Evidence for Middle Horizon to 16th Century Camelid Herding in the Osmore Valley, Peru." International Journal of Osteoarchaeology 21: 544-567.

Tieszen, L., and M. Chapman. 1992. "Carbon and Nitrogen Isotopic Status of the Major Marine and Terrestrial Resources in the Atacama Desert of Northern Chile." In
Proceedings of the First World Congress on Mummy Studies, 409-425. Santa Cruz de Tenerife: Museo Arqueológico y Etnográfico de Tenerife.

Tomczyk, W., and M. Giersz. 2017. "Polydactyly Suggesting Local Husbandry of Pre-Columbian Camelids: A Case from Castillo de Huarmey Archaeological Site, Northern Coast of Peru." International Journal of Paleopathology 16: $40-43$.

Ugent, D., and C. M. Ochoa. 2006. La etnobotánica del Perú: Desde la Prehistorial al Presente. Lima: Consejo Nacional de Ciencia, Tecnología e Innovación Tecnológica.

Verano J. W., and M. J. DeNiro. 1993. "Local or Foreigners? Morphological, Biometric and Isotopic Approaches to the Question of Group Affinity in Human Skeletal Remains Recovered from Unusual Archaeological Contexts." In Investigations of Ancient Human Tissue: Chemical Analysis in Anthropology, edited by M. K. Sandford, 261-386. Langhorne: Gordon and Breach.

Wester La Torre, C. 2016. Chornancap: Palacio de una gobernante y sacerdotista de la cultura Lamabyeque. Chiclayo: Ministerio de Cultura-Museo Brüning.

Wheeler, J. C. 1982. "Aging Llamas and Alpacas by Their Teeth.” Llama World 1: 12-17.

White, C. D., A. J. Nelson, F. J. Longstaffe, G. Grupe, and A. Jung. 2009. "Landscape Bioarchaeology at Pacatnamu Peru: Inferring Mobility from $\delta^{13} \mathrm{C}$ and $\delta^{15} \mathrm{~N}$ Values of Hair." Journal of Archaeological Science 36: 1527-1537.

Yacobaccio, H. D., M. R. Morales, and C. T. Samec. 2009. "Towards an Isotopic Ecology of Herbivory in the Puna Ecosystem: New Results and Patterns on Lama glama." International Journal of Osteoarchaeology 19: 144-155.

Zazzo, A., S. M. Harrison, B. Bahar, A. P. Moloney, F. J. Monahan, C. M. Scrimgeour, and O. Schmidt. 2007. "Experimental Determination of Dietary Carbon Turnover in Bovine Hair and Hoof." Canadian Journal of Zoology 85: 1239-1248. 